OPEN ACCESS

Edited by:

Dominique Job,

Centre National de la Recherche

Scientifique, France

Reviewed by:

Julia Buitink

National Institute for Agricultural

Research, France

Tiago Santana Balbuena

São Paulo State University, Brazil

*Correspondence:

Ana P. Barba de la Rosa apbarba@ipicyt.edu.mx

${ }^{\dagger}$ Present address:

Alma L. Saucedo,

Consejo Nacional de Ciencia y Tecnología, Laboratorio de RMN, Departamento de Química Analítica

Facultad de Medicina, Universidad

Autónoma de Nuevo León, Av.

Madero y Av. Gonzalitos s/n, Colonia

Mitras Centro, Monterrey, México;

Eric E. Hernández-Domínguez,

Consejo Nacional de Ciencia y

Tecnología-Instituto de Ecología, A.C.

Carretera antigua a Coatepec 351,

El Haya, Xalapa de Enríquez, México

Specialty section:

This article was submitted to

Plant Proteomics,

a section of the journal

Frontiers in Plant Science

Received: 22 December 2016

Accepted: 22 March 2017

Published: 07 April 2017

Citation:

Saucedo AL,

Hernández-Domínguez EE,

de Luna-Valdez $L A$

Guevara-García AA

Escobedo-Moratilla A,

Bojorquéz-Velázquez E,

del Río-Portilla F

Fernández-Velasco DA and Barba de la Rosa AP (2017) Insights on

Structure and Function of a Late

Embryogenesis Abundant Protein

from Amaranthus cruentus: An

Intrinsically Disordered Protein

Involved in Protection against Desiccation, Oxidant Conditions,

and Osmotic Stress.

Front. Plant Sci. 8:497.

doi: 10.3389/fpls.2017.00497

\section{Insights on Structure and Function of a Late Embryogenesis Abundant Protein from Amaranthus cruentus: An Intrinsically Disordered Protein Involved in Protection against Desiccation, Oxidant Conditions, and Osmotic Stress}

\begin{abstract}
Alma L. Saucedo ${ }^{1 \dagger}$, Eric E. Hernández-Domínguez ${ }^{1 \dagger}$, Luis A. de Luna-Valdez ${ }^{2}$, Angel A. Guevara-García ${ }^{2}$, Abraham Escobedo-Moratilla ${ }^{1}$, Esaú Bojorquéz-Velázquez', Federico del Río-Portilla ${ }^{3}$, Daniel A. Fernández-Velasco ${ }^{4}$ and Ana P. Barba de la Rosa ${ }^{1 \star}$

' Department of Molecular Biology, Instituto Potosino de Investigación Científica y Tecnológica, A.C., San Luis Potosí, México, ${ }^{2}$ Instituto de Biotecnología, Universidad Nacional Autónoma de México, Cuernavaca, México, ${ }^{3}$ Instituto de Química, Universidad Nacional Autónoma de México, Ciudad de México, México, ${ }^{4}$ Laboratorio de Fisicoquímica e Ingeniería de Proteínas, Departamento de Bioquímica, Facultad de Medicina, Universidad Nacional Autónoma de México, Ciudad de México, México
\end{abstract}

Late embryogenesis abundant (LEA) proteins are part of a large protein family that protect other proteins from aggregation due to desiccation or osmotic stresses. Recently, the Amaranthus cruentus seed proteome was characterized by 2D-PAGE and one highly accumulated protein spot was identified as a LEA protein and was named AcLEA. In this work, AcLEA cDNA was cloned into an expression vector and the recombinant protein was purified and characterized. AcLEA encodes a 172 amino acid polypeptide with a predicted molecular mass of $18.34 \mathrm{kDa}$ and estimated $\mathrm{p} /$ of 8.58. Phylogenetic analysis revealed that AcLEA is evolutionarily close to the LEA3 group. Structural characteristics were revealed by nuclear magnetic resonance and circular dichroism methods. We have shown that recombinant AcLEA is an intrinsically disordered protein in solution even at high salinity and osmotic pressures, but it has a strong tendency to take a secondary structure, mainly folded as $\alpha$-helix, when an inductive additive is present. Recombinant AcLEA function was evaluated using Escherichia coli as in vivo model showing the important protection role against desiccation, oxidant conditions, and osmotic stress. AcLEA recombinant protein was localized in cytoplasm of Nicotiana benthamiana protoplasts and orthologs were detected in seeds of wild and domesticated amaranth species. Interestingly AcLEA was detected in leaves, stems, and roots but only in plants subjected to salt stress. This fact could indicate the important role of AcLEA protection during plant stress in all amaranth species studied.

Keywords: amaranth seeds, circular dichroism, intrinsically disordered proteins (IDP), late embryogenesis abundant (LEA) proteins, nuclear magnetic resonance, Western blot 


\section{INTRODUCTION}

Seeds can withstand the loss of cellular water during the maturation phase of their development by the accumulation of high levels of ubiquitous proteins named late embryogenesis abundant (LEA) proteins (Ali-Benali et al., 2005; Dalal et al., 2009; Liu et al., 2013; Avelange-Macherel et al., 2015). LEA proteins were originally discovered in cotton (Gossypium hirsutum) seeds (Dure, 1989), but their accumulation is not only related to the development of desiccation tolerance in orthodox seeds (desiccation-tolerant seeds). LEA proteins are also induced upon water-related stress in plant vegetative tissues and in other anhydrobiotic organisms such as eubacteria, rotifers, nematodes, tardigrades, arthropods (Ingram and Bartels, 1996; Browne et al., 2002; Hundertmark and Hincha, 2008; Campos et al., 2013; Hatanaka et al., 2014; van Leeuwen et al., 2016). In some microorganisms, LEA proteins are reported in response to water limitation, which suggests that they have an important role in desiccation tolerance (Tunnacliffe and Wise, 2007; Tunnacliffe et al., 2010; Hand et al., 2011). In spite of their widely recognized importance for desiccation tolerance, the molecular function of LEA proteins is only starting to emerge, with a variety of functions in agreement with their diversity (Battaglia and Covarrubias, 2013).

The distinctive features of LEA proteins are their high hydrophilicity due to a high percentage of charged amino acids such as alanine, serine/threonine and the absence or very low content of non-polar amino acids (tryptophan and cysteine). The presence of repeated motifs, which tend to form secondary structures, has detected in LEA proteins (Dure, 1989; GarayArroyo et al., 2000; Tunnacliffe and Wise, 2007). Although LEA proteins are intrinsically disordered proteins (IDP) in aqueous solutions (Wolkers et al., 2001; Goyal et al., 2003; Boucher et al., 2010; Tompa and Kovacs, 2010; Popova et al., 2011), they may acquire some structure folding into $\alpha$-helical conformations during partial or complete dehydration (Shih et al., 2004; Tolleter et al., 2007; Hincha and Thalhammer, 2012).

Several hundreds of LEA protein sequences have been gathered in a dedicated database ${ }^{1}$ and bioinformatics analyses have shown that each LEA class can be clearly characterized by a unique set of physico-chemical properties. This has led to the classification of LEA proteins into 12 non-overlapping classes with distinct properties (Battaglia et al., 2008; Hunault and Jaspard, 2010; Jaspard et al., 2012).

Although quite a few LEAs have been characterized, the functions of most members of the LEA family remain unknown (Cao and Li, 2015). Transgenic Arabidopsis thaliana plants overexpressing the Nicotiana tabacum NtLEA7-3 gene are much more resistant to cold, drought, and salt stresses (Gai et al., 2011). Tomato LEA25 increases the salt and chilling stress tolerance when overexpressed in yeast (Imai et al., 1996). Wheat and rice over-expressing HVA1 gene (encoding

${ }^{1}$ http://forge.info.univ-angers.fr/ gh/Leadb an LEA protein from barley) are more tolerant to drought and salt stress (Xu et al., 1996; Sivamani et al., 2000). Olvera-Carrillo et al. (2010) reported that in A. thaliana, the accumulation of AtLEA4 protein leads to a drought tolerant phenotype. The overexpression of BnLEA4-1 from Brassica napus in Escherichia coli can enhance bacterial cellular tolerance to temperature and salt stresses (Dalal et al., 2009).

On the other hand, LEA proteins have a broad subcellular distribution; they are present in cytosol, mitochondria, chloroplasts, endoplasmic reticulum, and nucleus (Candat et al., 2014) and the specific modes of their action could be related to their intracellular location. The biological activity of these proteins seems to be associated with the stabilization of membranes during cell drying (Tolleter et al., 2010), and assistance of the transport of proteins during stress conditions (Chakrabortee et al., 2010).

Amaranth, a member of Amaranthaceae family, is a plant that has been cultivated and used since ancient times by Mexican and Central American civilizations. In the last decades, the nutritional role of amaranth seeds from different species has been revalued, particularly for A. hypochondriacus and A. cruentus, not only because of their high protein content and their contribution of essential amino acids, like lysine and methionine (compared to other grains), but also for their antioxidant compounds (Becker et al., 1981; Rastogi and Shukla, 2013), and bioactive peptides (Silva-Sánchez et al., 2008). Current interest in amaranth plants is also related to their extraordinary adaptability to grow in adverse weather conditions (Brenner et al., 2000). Amaranth is resistant against several types of stresses such as pest (ValdesRodríguez et al., 2007), heat (Maughan et al., 2009), drought (Huerta-Ocampo et al., 2011), and salinity (Aguilar-Hernández et al., 2011; Huerta-Ocampo et al., 2014). The recent report of Amaranthus cruentus seed proteome by 2D-PAGE revealed the over-accumulation of one spot identified as a LEA protein (Maldonado-Cervantes et al., 2014). In the present study, we have cloned the corresponding LEA cDNA from A. cruentus (AcLEA, GenBank accession no. KX852451), and the recombinant protein was expressed in E. coli. Nuclear Magnetic Resonance (NMR) and Circular Dichroism (CD) were used as tools to study the structural characteristics of this particular AcLEA protein. Its functional activity was evaluated in vivo using $E$. coli as model.

According to its amino acid sequence, AcLEA protein belongs to the Group 3, its hydrophilic nature and spectroscopic characteristics being ad hoc with IDP molecules, but exhibiting a high content of $\alpha$-helix in the presence of trifluoroethanol (TFE). Overexpression of AcLEA in E. coli conferred resistance to desiccation, osmotic and oxidative stress to the bacterial cells. When accumulated in a heterologous system (Nicotiana benthamiana protoplasts) the amaranth protein was found to be distributed in the cytoplasm of protoplasts. Western blot analyses disclosed that AcLEA protein accumulated in seeds of wild and domesticated amaranth species. Accumulation of AcLEA in leaves, stems, and roots was observed only in plants subjected to salinity stress. 


\section{MATERIALS AND METHODS}

\section{RNA Extraction and Cloning of the cDNA Encoding AcLEA}

Immature seeds (15 days after anthesis) of Amaranthus cruentus were used to extract total RNA with TRIzol Reagent (Invitrogen, Carlsbad, CA, USA) and cDNA was synthesized as previously reported (Maldonado-Cervantes et al., 2014). AcLEA cDNA was amplified using specific primers containing NdeI (5'-CATATGGCATCACATGGTCAGAGT- $\left.3^{\prime}\right)$ and XhoI (5'-CTCGAGCTAGGGCCTAGTAGTCTTAATTGGATC-3')

restriction sites. cDNA amplification was performed using Platinum Taq DNA polymerase (Invitrogen), under standard reaction conditions. The amplified PCR product was cloned into the plasmid pGEM-T-Easy (Promega Corp., Madison, WI, USA). AcLEA cDNA was excised from pGEM using NdeI and XhoI (New England Biolabs, Ipswich, MA, USA) restriction enzymes. Digested fragments were purified and subcloned into pET28 expression vector restricted with NdeI-XhoI (Novagen-Merck, Darmstadt, Germany) containing the His-Tag at N-terminal. Vector was modified to have a recognition cleavage site within the amino acid sequence LeuGluValLeuPheGln/GlyPro specific for human rhinovirus 3C protease as PreScission Protease (PSP), and ending with the pET28mod vector. The resulting plasmid pET28mod-AcLEA was sequenced in both directions to confirm the AcLEA cDNA identity.

Alternatively, the AcLEA cDNA was PCR flanked with attB1 and attB2 recombination sites for generation of an entry clone using the gateway system entry vector pDONR-Zeo (Karimi et al., 2007), which was later used to generate the expression vector pEarlyGate 103-AcLEA.

\section{Physicochemical Properties and Phylogenetic Analyses}

Protein hydrophilicity analysis was performed to obtain the hydropathy plots with the Kyte and Doolittle (1982) values from the Expasy ProtScale Tool ${ }^{2}$ (Gasteiger et al., 2005). Grand average of hydropathicity (GRAVY) and instability index were calculated using the ProtParam software ${ }^{3}$. Sequence similarities were determined using the BLAST program and the GenBank database on the NCBI web server. MUSCLE 3.8.31 (Edgar, 2004) was used to perform multiple sequence alignments of full-length protein sequences. The phylogenetic analyses of the LEA proteins based on amino acid sequences were carried out using the neighbor-joining method (Saitou and Nei, 1987). AcLEA protein classification was done comparing its sequence to those available in the LEA Proteins Data Base ${ }^{4}$ (Hunault and Jaspard, 2010) and the Pfam server ${ }^{5}$ (Finn et al., 2015).

AcLEA related protein sequences were retrieved from the recently reported genome of Amaranthus hypochondriacus (Clouse et al., 2016) deposited at Phytozome $v 12.0^{6}$.

\footnotetext{
${ }^{2}$ http://web.expasy.org/protscale/

${ }^{3}$ http://web.expasy.org/protparam/

${ }^{4}$ http://forge.info.univ-angers.fr/ gh/Leadb/index.php

${ }^{5}$ http://pfam.xfam.org/

${ }^{6}$ http://www.phytozome.net
}

\section{Expression and Purification of the Recombinant AcLEA Protein}

Recombinant AcLEA protein (rAcLEA) was up-accumulated in BL21 (DE3) E. coli cells (Novagen) transformed with the expression vector pET28mod-AcLEA. LB media supplemented with kanamycin was used to grow cells at $37^{\circ} \mathrm{C}$. Overnight cultures were diluted 100 -fold using fresh LB medium, and incubation was continued until optical density $\left(\mathrm{OD}_{600}\right)$ reached $0.5-0.6$. At this point, $0.1 \mathrm{mM}$ isopropyl thio- $\beta$-D-galacto-pyranoside (IPTG, Sigma-Aldrich, St. Louis, MO, USA) was added to induce the protein expression. After further $4 \mathrm{~h}$ of incubation at $28^{\circ} \mathrm{C}$, cells were harvested by centrifugation at $3,000 \times g$ for $15 \mathrm{~min}$ at $4^{\circ} \mathrm{C}$.

For structural studies cell pellets were resuspended in native buffer (150 mM NaCl, $50 \mathrm{mM}$ Tris- $\mathrm{HCl}, \mathrm{pH}$ 8) and for antibodies production cells pellets were resuspended in denaturing lysis buffer $(500 \mathrm{mM} \mathrm{NaCl}, 6 \mathrm{M}$ guanidine hydrochloride, $20 \mathrm{mM}$ sodium phosphate, $\mathrm{pH}$ 7.8). Resuspended pellets were sonicated for $45 \mathrm{~s}$ (Misonix Sonicator 3000, Cole-Parmer, Vernon Hills, IL, USA) in ice bath. Antibodies were obtained as described in Supplementary Information. The soluble fraction was separated by centrifugation at $20,000 \times g$ for $30 \mathrm{~min}$ at $4^{\circ} \mathrm{C}$. Recombinant six-His-tagged AcLEA (rHis-AcLEA, $20.7 \mathrm{kDa}$ ) was purified by metal-chelate affinity chromatography (IMAC) using the Ni-NTA agarose purification system (Novex, Thermo Fischer Scientific Inc., Waltham, MA, USA), and eluted with five volumes of native $(150 \mathrm{mM} \mathrm{NaCl}, 50 \mathrm{mM}$ Tris-HCl, $\mathrm{pH}$ 8.0) or denaturing elution buffer $(500 \mathrm{mM}$ $\mathrm{NaCl}, 8 \mathrm{M}$ urea, $20 \mathrm{mM}$ sodium phosphate, $\mathrm{pH} 4.0$ ). In both native and denaturing purifications, buffer exchange to $150 \mathrm{mM} \mathrm{NaCl}, 50 \mathrm{mM}$ Tris-HCl, pH 8.0, was performed by dialysis using a $5 \mathrm{kDa}$ cut-off membrane (Merck Millipore, Billerica, MA, USA), and cleavage of His-Tag was carried out overnight at $4^{\circ} \mathrm{C}$. After cleavage, a second step of IMAC purification was carried out under native conditions $(150 \mathrm{mM}$ $\mathrm{NaCl}, 50 \mathrm{mM}$ Tris- $\mathrm{HCl}, \mathrm{pH}$ 8.0) in order to obtain native rAcLEA. Since rAcLEA was found to be weakly bounded to the resin, a native buffer containing $20 \mathrm{mM}$ imidazole was used for protein elution. Finally, PD10 desalting columns (GE Healthcare, Piscataway, NJ, USA) were used to remove buffer components. For NMR spectroscopic and CD analyses, an additional purification step of rAcLEA was done using FPLC chromatography with a Sephacryl S-100 column (GE Healthcare) with a mobile phase of $10 \mathrm{mM}$ sodium phosphate pH 7.0 (Sigma-Aldrich). All rAcLEA purification steps were followed by $12 \%$ SDS-PAGE gels stained with Coomassie Blue.

Recombinant proteins, excised from gel and/or in solution after chromatography purification were reduced with $10 \mathrm{mM}$ DTT followed by protein alkylation with $55 \mathrm{mM}$ iodoacetamide, and finally digested with trypsin (Promega, Madison, WI, USA) in an overnight reaction at $37^{\circ} \mathrm{C}$. MS was carried out with a SYNAPT-HDMS (Waters Corp.) coupled to a nano-ACQUITY-UPLC system as described in Supplementary Information. 


\section{Structural and Functional Characteristics of AcLEA \\ NMR and CD Analyses}

Lyophilized rAcLEA purified under native conditions was dissolved in $\mathrm{H}_{2} \mathrm{O} / \mathrm{D}_{2} \mathrm{O}$ (95:5) to prepare a solution at final concentration of $1 \mathrm{mM}$, and transferred to a $3 \mathrm{~mm}$ tube. For ${ }^{1} \mathrm{H}-\mathrm{NMR}$ water suppression signal was performed using the double-pulsed field gradient spin echo sequence (DPFGSE). Fourier transformation was applied to FID file and data were analyzed with the NUTS Data Processing Software (Acorn NMR Inc., Livermore, CA, USA). Proton nuclear magnetic resonance spectra ( $\left.{ }^{1} \mathrm{H}-\mathrm{NMR}\right)$ were acquired on a $500 \mathrm{MHz}$ Varian Innova spectrometer (Varian, Palo Alto, CA, USA) at $298 \mathrm{~K}$.

Circular dichroism spectra were recorded on a Chirascan Circular Dichroism Spectrometer (Applied Photophysics, Leatherhead, UK), equipped with a Peltier cell holder for control of temperature. A stock solution of rAcLEA protein $(0.4 \mathrm{mg} / \mathrm{ml})$ was prepared in $10 \mathrm{mM}$ phosphate buffer $\mathrm{pH}$ 8.0. Far UV CD spectra were obtained using a quartz cell with a light path of $1 \mathrm{~mm}$ in the $200-260 \mathrm{~nm}$ range with a bandwidth of $1.0 \mathrm{~nm}$ and a digital resolution of $0.5 \mathrm{~s}$ per point. Temperature-induced conformational changes were simultaneously recorded at 210 , 222 and $230 \mathrm{~nm}$ using a heating rate of $1^{\circ} \mathrm{C} / \mathrm{min}$ in the 20 to $70^{\circ} \mathrm{C}$ range. After the heating ramp, the sample was cooled to $20^{\circ} \mathrm{C}$ then far UV CD spectra was taken to determine the reversibility of the conformational changes. CD spectra in the near UV region covering the $250-350 \mathrm{~nm}$ range were recorded using a quartz cell with a $10 \mathrm{~mm}$ path length, bandwidth of $2.0 \mathrm{~nm}$ and $1.0 \mathrm{~s}$ time per point. Molar ellipticity values, $[\theta]$, were calculated from measured $\theta$ using the equation:

$$
[\theta] \operatorname{deg} \mathrm{cm}^{2} \mathrm{dmol}^{-1}=\theta \cdot \mathrm{M} \cdot 100 / \mathrm{c} \cdot l
$$

where $\theta$ is the measured ellipticity in degrees, $\mathrm{M}$ is the protein molecular weight, $\mathrm{c}$ is the protein concentration in $\mathrm{mg} / \mathrm{ml}$, and $l$ is the path length. Estimation of secondary structure was performed using the CDNN algorithm (Bohm et al., 1992) using a spectral window data from 200 to $260 \mathrm{~nm}$. Five spectra were recorded for each experimental condition.

\section{Assay of Protective Role of AcLEA in E. coli}

Transformed E. coli BL21 cells carrying the plasmid pET28modAcLEA and the empty plasmid pET28mod (control) were grown in LB liquid medium supplemented with $37 \mu \mathrm{g} / \mathrm{ml}$ kanamycin overnight at $37^{\circ} \mathrm{C}$. For both bacterial cultures, an aliquot was diluted 100-fold using fresh liquid LB with antibiotic and allowed to grow for $2-3 \mathrm{~h}$ at $37^{\circ} \mathrm{C}$. When $\mathrm{OD}_{600}$ reached $0.5-0.6$, IPTG was added to a final concentration of $0.1 \mathrm{mM}$ and cultures were kept at $28^{\circ} \mathrm{C}$ for $2 \mathrm{~h}$, for rAcLEA protein induction. At this point stress treatments were analyzed. To test the function of AcLEA protein to prevent desiccation stress, E. coli cells were dried at $40^{\circ} \mathrm{C}$ for $2 \mathrm{~h}$ in a flat plates under the laminar flow hood. After drying, cells were rehydrated in $200 \mu \mathrm{l}$ of liquid LB media. Resuspended cells were spread over Petri dishes containing LB, antibiotic, and IPTG, then were incubated overnight at $37^{\circ} \mathrm{C}$.
The number of colony former units (CFU) was used to compare viability (Dalal et al., 2009; He et al., 2012). Salinity stress was assessed with different concentrations of $\mathrm{NaCl}(0.4,0.6$, and $0.8 \mathrm{M})$. Sorbitol $(0.6,0.8$, and $1.0 \mathrm{M})$ and PEG $4000(5,10$, and $20 \% \mathrm{w} / \mathrm{v}$ ) were used to decrease osmotic potential and mimic dehydration, and $\mathrm{H}_{2} \mathrm{O}_{2}(0.1,0.5$, and $1.0 \mathrm{M})$ was tested to promote oxidant conditions. In all experiments, absorbance at $600 \mathrm{~nm}\left(\mathrm{OD}_{600}\right)$ was used to measure the bacterial growth in liquid media (Liu and Zheng, 2005; Wu et al., 2014; Hu et al., 2016). All experiments were carried out in three biological replicates each replicate was done at least three times.

\section{Localization In vivo Using Nicotiana benthamiana Protoplasts}

The expression vector pEarlyGate103-AcLEA was transferred to Agrobacterium tumefaciens $\mathrm{C} 58 \mathrm{C} 1$ by electroporation in $0.1 \mathrm{~cm}$ gap cuvettes. A single colony was used to inoculate LB broth supplemented with ampicillin $(100 \mu \mathrm{g} / \mathrm{ml})$, rifampicin $(100 \mu \mathrm{g} / \mathrm{ml})$, and kanamycin $(50 \mu \mathrm{g} / \mathrm{ml})$. The inoculated broth was cultivated at $30^{\circ} \mathrm{C}$ overnight. To ensure high expression levels of the recombinant protein, A. tumefaciens cells containing the expression clone were used along the helper strain p19 (Voinnet et al., 2003). A. tumefaciens cells were harvested by centrifugation at $1,400 \times g$ at room temperature and resuspended in an aqueous solution of $10 \mathrm{mM} \mathrm{MgCl}$. Dilutions were made to adjust a final $\mathrm{OD}_{600}$ of 1.0 in the infiltration solution of both the p19 helper strain and the experimental strain (carry on the pEarlyGate103-AcLEA expression vector). Then acetosyringone $(50 \mu \mathrm{g} / \mathrm{ml})$ was added to the infiltration solution and incubated at room temperature for $3 \mathrm{~h}$. This bacterial solution was used to infiltrate $N$. benthamiana leaves and the treated plants were incubated for $96 \mathrm{~h}$ in regular growth conditions $\left(26^{\circ} \mathrm{C}\right.$ and $16 / 8 \mathrm{~h}$ light/dark cycle) prior the protein extraction or protoplasts preparation.

Total protein was extracted from infiltrated leaves by $10 \mathrm{~min}$ incubation in extraction buffer (70 mM Tris- $\mathrm{HCl}, \mathrm{pH} 8.0,1 \mathrm{mM}$ $\mathrm{MgCl}_{2}, 25 \mathrm{mM} \mathrm{KCl}, 5 \mathrm{mM} \mathrm{NaEDTA} \cdot 2 \mathrm{H}_{2} \mathrm{O}, 0.25 \mathrm{mM}$ sucrose, $7.5 \mathrm{mM}$ DTT, $0.1 \% \mathrm{v} / \mathrm{v}$ Triton X-100) followed by centrifugation at $16,000 \times g$ for $10 \mathrm{~min}$ at $4^{\circ} \mathrm{C}$. The protein extracts were analyzed by Western blot using anti-GFP (Invitrogen) and antiAcLEA specific antibodies. Protoplasts were released from the leaf tissue by incubation in enzyme solution composed of $0.5 \mathrm{M}$ mannitol, 1\% w/v cellulase R10 (KARLAN Research Products Corp., Cottonwood, AZ, USA) and $0.05 \%$ w/v macerozyme R10 (KARLAN Research) and leaf tissue was incubated in this solution for $3 \mathrm{~h}$ at constant agitation $(1,400 \times g)$. Confocal microscopy images were obtained with an Olympus FV1000 microscope (Olympus, Center Valley, PA, USA) using excitation lasers of $633 \mathrm{~nm}$ for chlorophyll and $514 \mathrm{~nm}$ for GFP.

\section{Detection of AcLEA in Seeds, Leaves, Stems, and Roots from Different Amaranth Species}

Proteins from seeds, leaves, stems, and roots were extracted from wild (A. hybridus and A. powellii) and domesticated (A. cruentus and $A$. hypochondriacus) amaranth species. 
Seeds were milled under liquid nitrogen in order to obtain a fine powder and proteins were extracted according to their solubility properties. Aqueous soluble proteins were extracted with buffer containing $10 \%$ glycerol, $0.1 \mathrm{M}$ Tris- $\mathrm{HCl}, \mathrm{pH} 8.0$ in a relation 1:20 (flour/buffer). Suspension was mixed with vortex for $15 \mathrm{~min}$ at $4^{\circ} \mathrm{C}$ and centrifuged at $17,000 \times g$ at $4^{\circ} \mathrm{C}$, supernatant was recovered and named as hydrophilic fraction. Resulting pellet was resuspended in $7 \mathrm{M}$ urea, $2 \mathrm{M}$ thiourea, $2 \%$ CHAPS (w/v), 2\% Triton X-100, $0.05 \mathrm{M}$ DTT and mixed as indicated above. The solubilized proteins (hydrophobic fraction) were recovered by centrifugation for $15 \mathrm{~min}$ at $17,000 \times g$ at $4^{\circ} \mathrm{C}$.

Proteins from leaves, stems, and roots were extracted from plants growing under normal and salt stress conditions. Seeds were germinated and seedlings were transferred to plastic pots with soil (Peat Moss Tourbe, Premier Horticulture, Rivière-duLoup, QC, Canada). Amaranth seedlings were divided in two groups; the control and the salt-stressed groups, which were watered with water and water containing $150 \mathrm{mM} \mathrm{NaCl}$ (EC 16.9-17.2 ds/m), respectively. Samples from control and saltstressed plants were collected next day after salt-stress imposition. Tissues were collected from three biological replicates containing three plants for each replicate. Samples were collected and immediately frozen in liquid nitrogen and milled to a fine powder as reported before (Huerta-Ocampo et al., 2014). The powder was suspended in extraction buffer $(1: 10 \mathrm{w} / \mathrm{v})$ containing $7 \mathrm{M}$ urea, $2 \mathrm{M}$ thiourea, 2\% Triton X-100, and 0.1 M 2-mercaptoethanol. The mixture was sonicated (GE-505, Ultrasonic Processor, Sonics \& Materials, Inc., Newtown, CT, USA) for $15 \mathrm{~min}$ at $4^{\circ} \mathrm{C}$ and centrifuged as above.

Proteins $(10 \mu \mathrm{g})$ were separated in a $12 \%$ SDS-PAGE and resolved at 75/150 V for $90 \mathrm{~min}$ and then transferred to a PVDF membrane using a Trans-Blot SD semi-dry transfer cell (Bio-Rad, Hercules, CA, USA) for $45 \mathrm{~min}$ at $15 \mathrm{~V}$ in transfer buffer $(25 \mathrm{mM}$ Tris, $192 \mathrm{mM}$ glycine). Membranes were blocked for $2 \mathrm{~h}$ with $5 \%$ defatted milk in TBS containing $0.1 \%$ Tween-20 (TBST), washed three times for $10 \mathrm{~min}$ with TBST and incubated with anti-AcLEA IgG rabbit polyclonal antibody for $2 \mathrm{~h}$ at 1:1,000 dilution in TBST. Membranes were washed three times for 10 min each with TBST, incubated with anti-rabbit IgG-alkaline phosphatase antibody (Sigma-Aldrich) for $90 \mathrm{~min}$ at 1:10,000 dilution in TBST. After membranes were washed three times for $10 \mathrm{~min}$ with TBST. Western blots were revealed with alkaline phosphatase buffer (0.1 M Tris, pH 9.5, $0.1 \mathrm{M} \mathrm{NaCl}, 5 \mathrm{mM} \mathrm{MgCl}_{2}$ ) and $0.5 \mathrm{mM} \mathrm{BCIP,}$ $0.4 \mathrm{mM}$ NBT for $10-20 \mathrm{~min}$ at $37^{\circ} \mathrm{C}$.

\section{RESULTS AND DISCUSSION}

\section{AcLEA Cloning and Recombinant Protein Expression in E. coli System}

Bioinformatics analyses, using LC-MS/MS information (Maldonado-Cervantes et al., 2014) and the A. hypochondriacus transcriptome (Delano-Frier et al., 2011), allowed us to design specific primers for cloning the full-length AcLEA cDNA. Amplified AcLEA fragment was ligated into pET28mod vector (Supplementary Figures S1A,B).
AcLEA cDNA contains an ORF of 516 bp that codifies for a 172 amino acids protein with a molecular mass calculated of $18.34 \mathrm{kDa}$ and a theoretical $\mathrm{p} I$ of 8.58 , values that corresponded to experimental data previously reported (Maldonado-Cervantes et al., 2014). The sequence (Supplementary Figure S2A) was deposited in the GenBank with access code KX852451. In order to identify AcLEA similar proteins and consensus sequences, a search was performed using protein BLAST algorithm and multiple alignment was carried out with the sequences of the highest similarity matches (Figure 1A). A search of related sequences in the LEAPdb database (Hunault and Jaspard, 2010) confirmed that all these sequences are grouped in the LEA_4 Pfam (PF02987). According to the classification proposed by Battaglia et al. (2008), in this family are included LEA proteins from Group 3, such as the cotton protein D7 (Dure, 1993). Group 3 LEA proteins are characterized by a repetitive motif of 11 amino acids TAQAAKDKTSE (motif 3 ) in the middle of the sequence that is preceded or followed by ATEAAKQKASE (motif 5); in the N-terminal region is usually conserved the SYKAGETKGRKT (motif 4); meanwhile GGVLQQTGEQV (motif 1) and AADAVKHTLGM (motif 2 ) are frequently observed in the C-terminal. In many proteins motifs 3 and 5 are present more than once. Motifs 1 to 5 were detected in AcLEA wherein the motif arrangement is M4-M5-M3-M1-M2 with only one complete motif of each type (Figure 1A). On the other hand, the motifs arrangement for LEA group 6 is in the order M3-M1-M2-M4 (Rivera-Najera et al., 2014).

With these sequences was constructed the phylogenetic tree in which was also included commercial crops such as: Zea mays (NP_001150813.1), Phaseolus vulgaris (PvLEA_18 and PVLEA4-25), Triticum aestivum (AHZ35571.1), Oryza sativa (LEA_3 ABS44867.1 and CAA92106.1), and other crops such a Vitis amurensis (ADY17817.1), Vitis vinifera (XP_002285360.1), Nicotiana sylvestris (XP_009770536.1), Nicotiana tabacum (XP_016459037.1), Capsicum aпnuum (XP_016562822.1), Catharanthus roseus (AAY84145.1), Camelina sativa (010487398.1), Solanum tuberosum (XP_006364193.1), Arabidopsis lyrata subsp. lyrata (ARALYDRAFT_474395), among others. The phylogenetic tree shows that LEA denominated Dc3 from B. vulgaris (sugar beet, XP_010691209.1) shared the highest homology with AcLEA (Figure 1B), while the LEA-14 from A. thaliana (1X08, At1g01470) which structure has been reported (Singh et al., 2005) showed low similarity with AcLEA as well as for LEA proteins from the commercial cereals and legumes.

AcLEA shares a similar amino acid composition as other LEA proteins, being rich in alanine (19.2\%), lysine (14.0\%), glutamic acid $(9.9 \%)$, glutamine $(9.3 \%)$, threonine $(9.3 \%)$, and glycine (8.1\%) (Battaglia et al., 2008; Denekamp et al., 2010). The total number of negatively charged residues (Asp and Glu) is 27, meanwhile positive charged residues (Arg and Lys) is 29. Another characteristic of AcLEA is the lack of Trp and Cys residues. AcLEA has an aliphatic index of 29.36 with a grand average of hydropathicity (GRAVY) computed of -1.23 , indicating a higher abundance of hydrophilic amino acids. Based on the AcLEA amino acid sequence, the hydropathic profile was calculated using the Kyte and Doolittle (1982) values, results showing that 
A

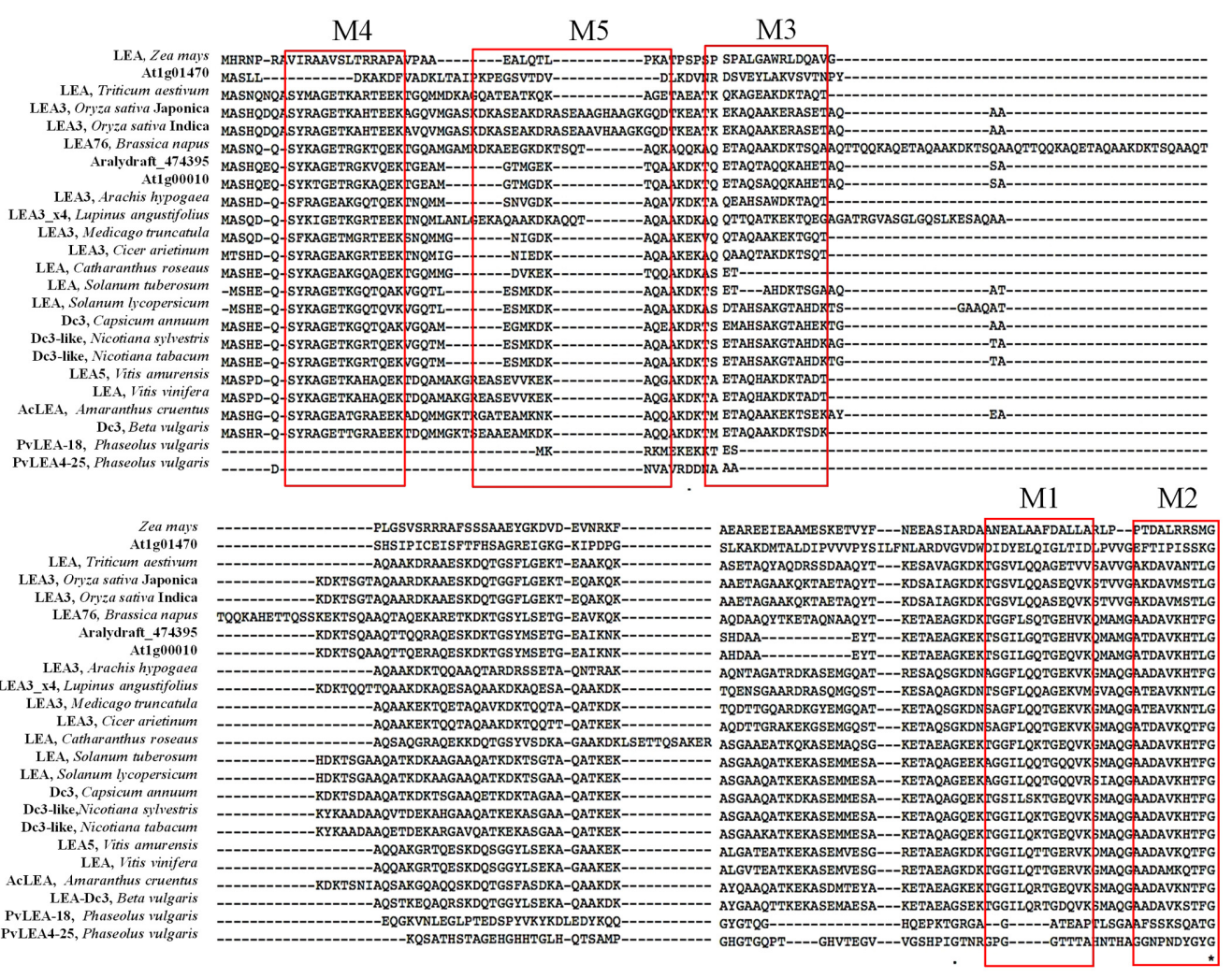

B

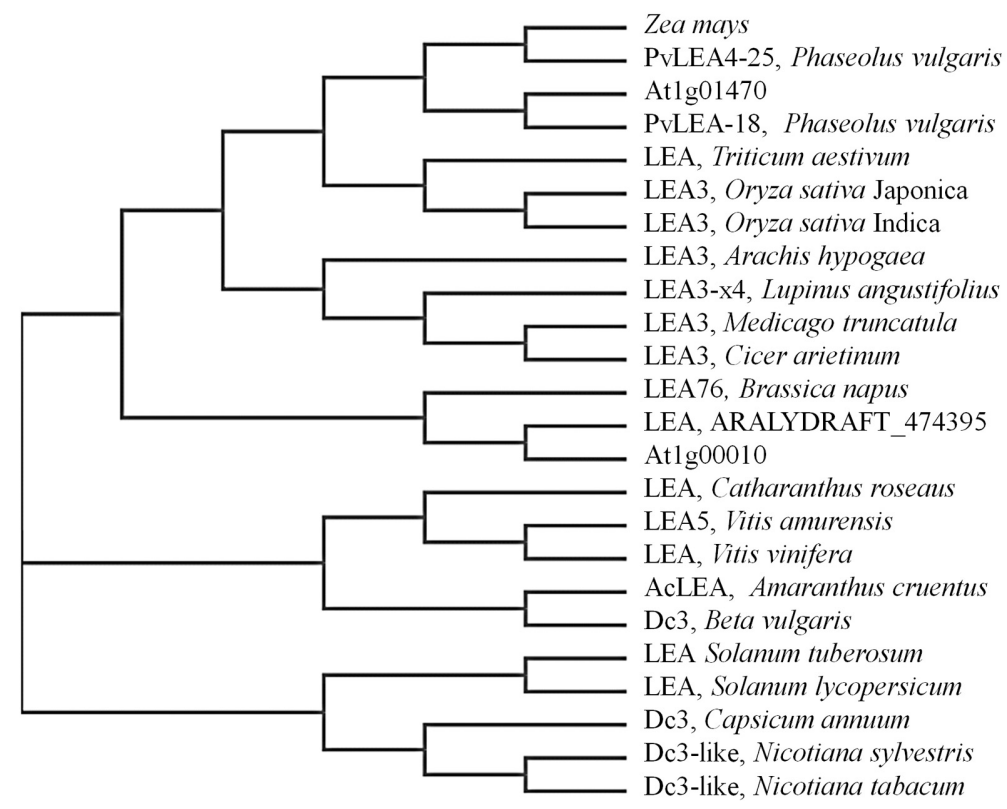

FIGURE 1 | (A) MUSCLE multiple sequence alignment of AcLEA isolated from immature seeds of Amaranthus cruentus. The red boxes show the category and position of the conserved motifs. (B) Phylogenetic tree constructed using the neighbor-joining method based on the multiple sequences alignment. Accessions numbers of published sequences in the GenBank are as follows: Amaranthus cruentus (AcLEA, KX852451), Beta vulgaris LEA_Dc3 (XP_010691209.1), Vitis amurensis LEA5 (ADY17817.1), Brassica napus LEA76, Vitis vinifera (XP_002285360.1), Arabidopsis thaliana LEA7 (AT1G00010), Arabidopsis thaliana LEA 1X08_A (AT1G01470), Arabidopsis lyrata subsp. Iyrata (ARALDYDRAFT_47395), Cicer arietinum LEA3 (XP_004506901.1), Medicago truncatula LEA3 (XP_013454682.1), Lupinus angustifolius LEA3 (XP_019454903.1), Arachis hypogaea LEA3 (ADQ91835.1), Oryza sativa Indica LEA3 (CAA92106.1), Oryza sativa Japonica LEA3 (ABS44867.1), Triticum aestivum (AHZ35571.1), PVLEA4-25 and PvLEA18 from Phaseolus vulgaris (AAC49862.1 and AAC49859.1, respectively), Zea mays (NP_001150813.1), Catharanthus roseus (AAY84145.1), Solanum tuberosum LEA 2-like (XP_006364193.1), Solanum lycopersicum (NP_001238798.1), Capsicum annuum DC3 (XP_016562822.1), Nicotiana sylvestris Dc3-like (XP_009770536.1), Nicotiana tabacum Dc3-like (XP_016459037.1). 
the hydrophilic character of this protein is clearly exhibited (Supplementary Figure S2B), as well AcLEA was predicted as disordered structure (Supplementary Figure S2C). The term hydrophilins was coined to the group of proteins with an average hydrophilicity index $>1$ and at least $6 \%$ Gly. Since hydrophilicity index is 1.23 and the Gly content is $8.1 \%$, AcLEA protein fits in the definition of hydrophilins (Garay-Arroyo et al., 2000).

\section{Protein Expression and Purification}

Two distinctive bands putatively corresponding to the recombinant AcLEA were detected in SDS-PAGE, one of them was located at $21.4 \mathrm{kDa}$, correlating with the molecular weight expected for recombinant protein linked to His-tag, the second band was located at $16.0 \mathrm{kDa}$ (Figure 2). The identities of these two bands were successfully identified by LC-MS/MS and bioinformatics analysis using $A$. hypochondriacus database (Supplementary Figure S3). Sequences of the matched peptides as well MASCOT scores are shown in Table 1. Data confirm that both the 21.4 and $16.0 \mathrm{kDa}$ bands corresponded to AcLEA. Nevertheless peptides in the $\mathrm{N}$-terminal region were not detected in the $16.0 \mathrm{kDa}$ product, indicating that this short protein is a truncated fragment lacking the $\mathrm{N}$-terminal region.

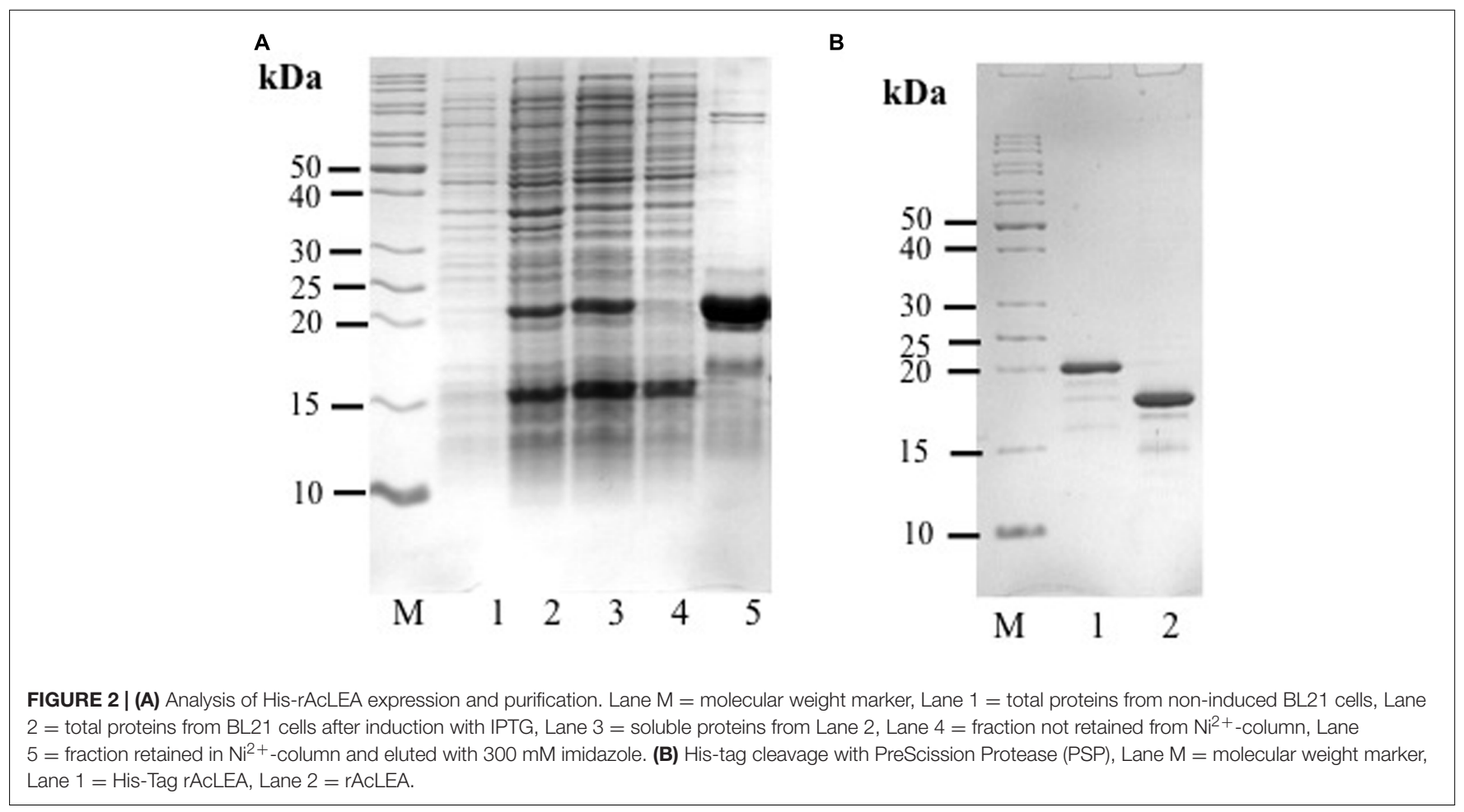

TABLE 1 | Recombinant AcLEA protein identities by LC-MS/MS.

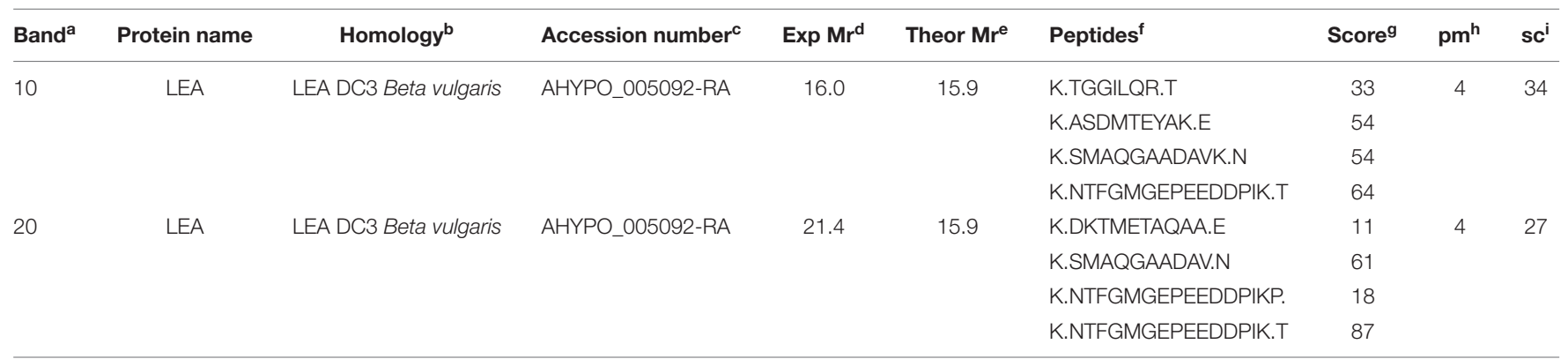

a 10 and $20 \mathrm{kDa}$ bands from Figure $2 \mathrm{~A}$ and Supplementary Figure S3.

${ }^{b}$ Best homology as Blast and Muscle-Clustal analysis (Figure 1).

c Accession number according to Amaranthus hypochondriacus transcriptome (phytozome.jgi.doe.gov) and similar to Late embryogenesis abundant protein 76 (Brassica napus).

d Experimental mass $(\mathrm{kDa})$ of identified proteins.

e Theoretical mass $(\mathrm{kDa})$ of identified proteins retrieved from the databases.

${ }^{\mathrm{f}}$ /dentified peptide sequences.

9 MASCOT score for each of identified peptides.

${ }^{\mathrm{h}}$ Number of unique peptides matched with late embryogenesis abundant (LEA) sequence.

i Sequence coverage (\%). 
The $21.4 \mathrm{kDa}$ His-rAcLEA was retained on the $\mathrm{Ni}^{2+}$ column and was eluted continuously with successive low concentrations of imidazole $(50 \mathrm{mM})$ washes, but high imidazole concentration (300 $\mathrm{mM}$ ) was required to completely recover the rAcLEA (Figure 2A and Supplementary Figure S4). The 15.4 kDa rAcLEA was not retained by $\mathrm{Ni}^{2+}$ column, confirming that this protein is a truncated fragment lacking of N-terminal His-Tag, which was confirmed by MS/MS analysis (Table 1 and Supplementary Figure S3). After exchange buffer by dialysis, the His-Tag was removed by PSP protease cleavage and rAcLEA purification was carried out again using $\mathrm{Ni}^{2+}$-NTA resin (Figure 2B). Retention of cleaved rAcLEA in this stationary phase can be explained because after the proteolysis cleavage residues added to the $\mathrm{N}$-terminal include Gly-Pro-His, and since AcLEA possesses a His in position 4 (Met-Ala-Ser-His), this combination of two histidine residues in relative positions 1-4 seems to be responsible for the rAcLEA binding to $\mathrm{Ni}^{2+}$-NTA resin.

For spectroscopic analysis it is desirable to have a protein purity greater than $98 \%$ (Acton et al., 2005). To ensure this experimental condition it was necessary to use a final chromatographic purification step based on molecular exclusion. Both rAcLEA proteins purified by native and denaturing conditions were eluted in a Sephacryl S-100 column with $10 \mathrm{mM}$ sodium phosphates buffer at $\mathrm{pH} 7.0$ as mobile phase; no changes were detected in retention time between them. Typical chromatographic profile shows only one well-defined peak and rAcLEA showed higher purity (Supplementary Figures S5A,B).

\section{Nuclear Magnetic Resonance Spectroscopy}

rAcLEA obtained under native conditions was used to evaluate the structural conformation of the recombinant protein by proton nuclear magnetic resonance. Uni-dimensional ${ }^{1} \mathrm{H}-\mathrm{NMR}$ spectrum provides general overviews of protein structure because chemical shifts values are strongly related with the presence of different elements of secondary structure (Wishart et al., 1991; Mielke and Krishnan, 2009). Particularly, $\mathrm{H}_{\mathrm{N}}$ amide protons are widespread from 6 to $11 \mathrm{ppm}$ in proteins with a well-defined tridimensional folding with a high content of $\alpha$-helix and $\beta$-strand. In contrast, $\mathrm{H}_{\mathrm{N}}$ resonances of unfolded proteins with a random coil conformation collapse in a narrow region around 7-8 ppm (Singh et al., 2005). Figure 3 shows the ${ }^{1} \mathrm{H}-\mathrm{NMR}$ spectrum of native rAcLEA, as can be observed amide and aromatic protons are distributed between 6.8 and $8.6 \mathrm{ppm}$, suggesting a random conformation. Moreover, $\mathrm{H} \alpha$ resonances around $4.1 \mathrm{ppm}$ have also a compact distribution, which is consistent with random coil as well the absence of splitting due to coupling in aliphatic signals in the $0.8-2.0 \mathrm{ppm}$ range. This spectroscopic patterns indicate that methyl and methylene groups present in aliphatic amino acid lateral chains have free rotation without limitations due to steric impediment, suggesting that rAcLEA in the experimental conditions tested lacks secondary and tertiary structure. In fact, rAcLEA possesses the typical NMR profile for IDP previously observed in a LEA protein of $T$. aestivum (Sasaki et al., 2014) and a dehydrin of A. thaliana (Agoston et al., 2011).

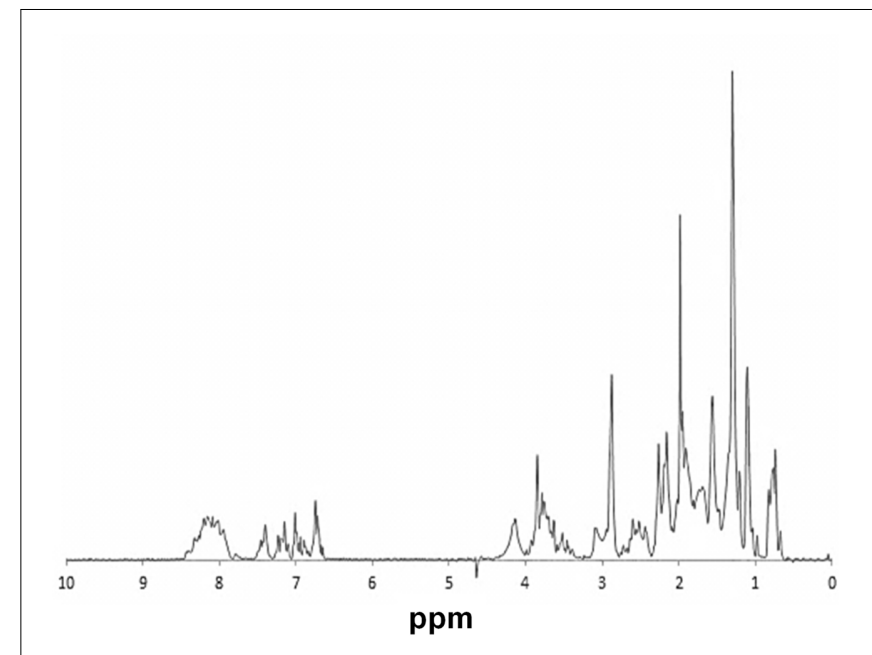

FIGURE 3 | NMR. ${ }^{1} \mathrm{H}-\mathrm{NMR}$ spectrum of HisAcLEA purified from native conditions. Narrow signal distribution in amide region, between 6.5 and $8.5 \mathrm{ppm}$, strongly suggest the lack of a well-defined tridimentional structure distintive of intrinsically disordered proteins.

\section{Circular Dichroism Spectroscopy}

The amino acid composition of AcLEA is rich in $\alpha$-helix promoters such as Ala (19.0\%), Met (5.2\%), Glu (9.8\%), Gln (9.2\%), Thr (9.2\%), and Lys (13.8\%), nevertheless the Gly content is high $(8.1 \%)$ this amino acid does not have a high propensity for secondary structure formation (Serrano et al., 1992; Creighton, 1993). As observed in other LEA proteins, secondary structure prediction indicates the formation of vast segments of helical structures reaching up to $80 \% \alpha$-helix content. Interestingly, NMR data (Figure 3) showed that in the experimental tested conditions rAcLEA has the spectral profile of an IDP. Therefore, in order to further explore the conformational properties of rAcLEA, CD spectra were recorded in the far UV region. rAcLEA was dissolved in $10 \mathrm{mM}$ phosphate buffer $\mathrm{pH} 8.0$ at different $\mathrm{NaCl}$ or sorbitol concentrations (Furuki et al., 2011; Wu et al., 2014; Warner et al., 2016). As shown in Figure 4A, the AcLEA spectra were not modified by $\mathrm{NaCl}$ nor sorbitol presence. All these CD spectra show a negative signal near $200 \mathrm{~nm}$ and weak bands in the 210-220 region, suggesting a low secondary structure content. In agreement, the deconvolution of the spectra using the CDNN program (Bohm et al., 1992) indicates a limited content of secondary structure (Supplementary Table S1). Because it is well known that the temperature-induced conformational changes (Soulages et al., 2002), then the curves as a function of temperature at different wavelengths (210, 222, and $230 \mathrm{~nm}$ ) were followed. For all samples at all the wavelengths tested, the ellipticity signal barely changed with temperature (Figure 4B). In agreement, the spectra obtained at $20^{\circ} \mathrm{C}$ before and after the heating cycle as well as that obtained at $75^{\circ} \mathrm{C}$ were very similar (Supplementary Figure S6). The lack of a temperature-induced transition strongly suggests that if secondary structure segments are formed, those segments are fluctuating and do not participate in the compact core structure. 
A

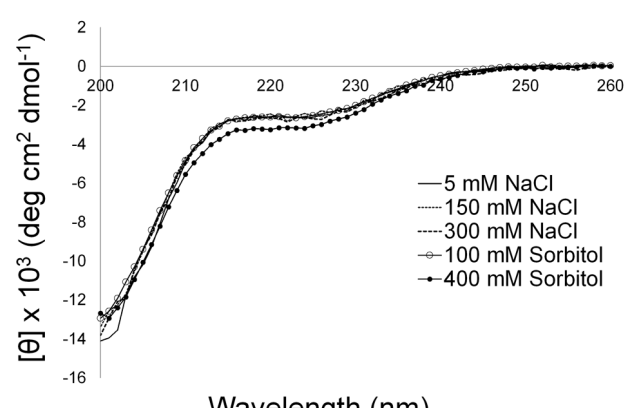

Wavelength $(\mathrm{nm})$

C

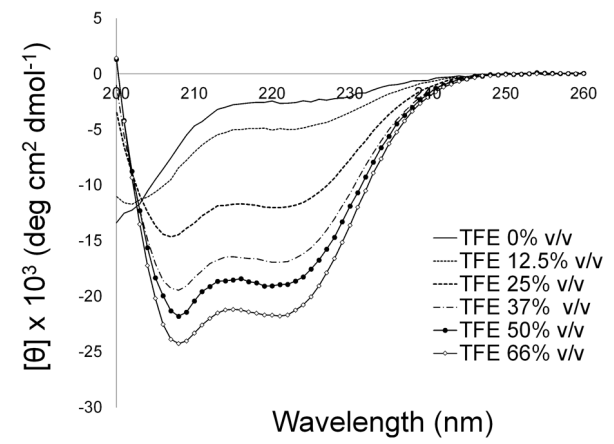

E

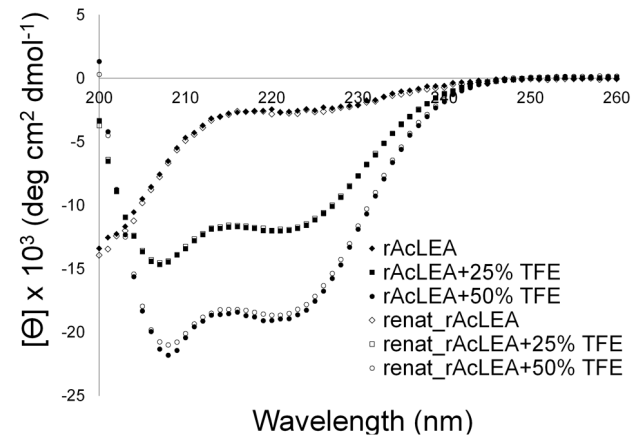

B

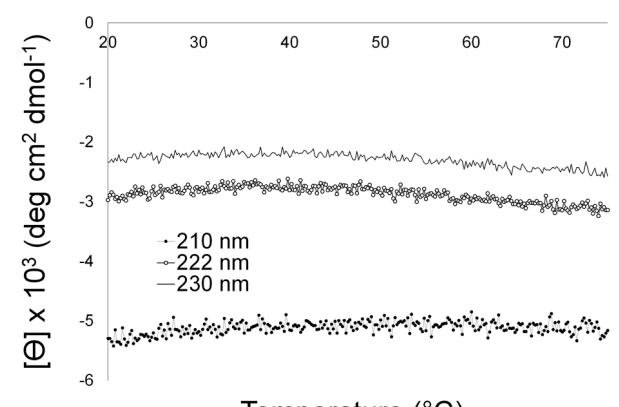

Temperature $\left({ }^{\circ} \mathrm{C}\right)$

D

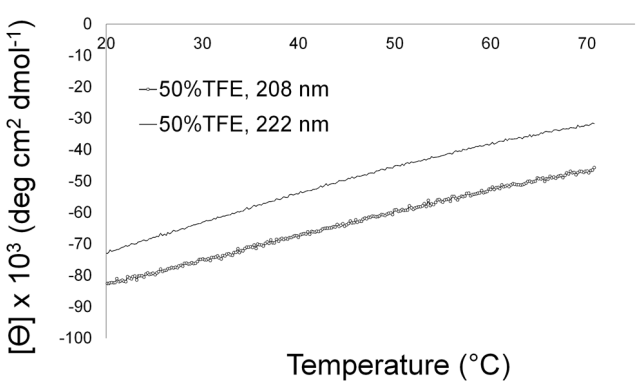

$\mathbf{F}$

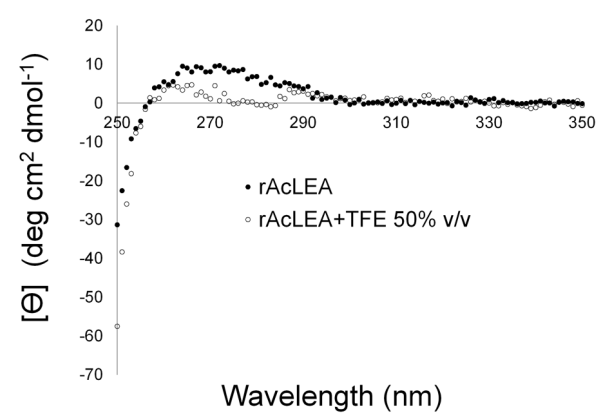

FIGURE 4 | Circular dichroism spectroscopy of rAcLEA under different environment conditions. (A) Far circular dichroism (CD) spectra of rAcLEA in presence of $\mathrm{NaCl}$ and sorbitol. (B) Recombinant AcLEA (5 mM NaCl, $10 \mathrm{mM}$ phosphates, pH 8, melting monitoring at 210, 222, and $230 \mathrm{~nm}$. (C) CD spectra of rAcLEA at different concentrations of trifluoroethanol (TFE), an additive that induce $\alpha$-helix folding. (D) Melting denaturing of $\alpha$-helix rAcLEA folded with $50 \%$ v/v TFE. (E) Folding recovery after melting. (F) Near CD spectra of rAcLEA in buffer solution with $50 \% \mathrm{v} / \mathrm{v}$ TFE.

It is well established that TFE can induce $\alpha$-helix folding in peptides (Buck, 1998; Boswell et al., 2014), as well as in unstructured proteins with a predisposition to form secondary structure such as LEA proteins (Shih et al., 2004; Rivera-Najera et al., 2014). Therefore the effect of TFE was evaluated on the rAcLEA conformation. Far UV CD spectra clearly show the tendency of rAcLEA to adopt helical structure as TFE concentration increases (Figure 4C). At TFE concentrations higher than $25 \%$, the CD spectra of rAcLEA show the distinctive minima at 208 and $222 \mathrm{~nm}$ characteristic of $\alpha$-helix structures (Muller et al., 2008). As TFE concentration increased up to $66 \%$ a gain of helical structure up $70.7 \%$ and a decreased in all the other types of secondary structure were observed (Figure 5 and Supplementary Table S1), this result being quantitatively confirmed using the CDNN program (Supplementary Table S1). In order to determine if this increase in helical content was accompanied with the formation of a structured core, the effect of temperature on rAcLEA dissolved in 50\% TFE was assayed. It was found that the ellipticity signal at 208 and $222 \mathrm{~nm}$ was lost in a non-cooperative way (Figure 4D) and changes in $\mathrm{CD}$ signal were fully reversible at 25 and 50\% TFE (Figure 4E). This strongly suggests that the helical segments induced by the addition of TFE are not arranged in a well-folded tertiary structure. To further explore the formation of tertiary structure, the CD spectra of rAcLEA in the aromatic region were also determined. In the absence of TFE, rAcLEA showed a weak signal in the region corresponding to Tyr and Phe residues, the intensity at $270 \mathrm{~nm}$ band 


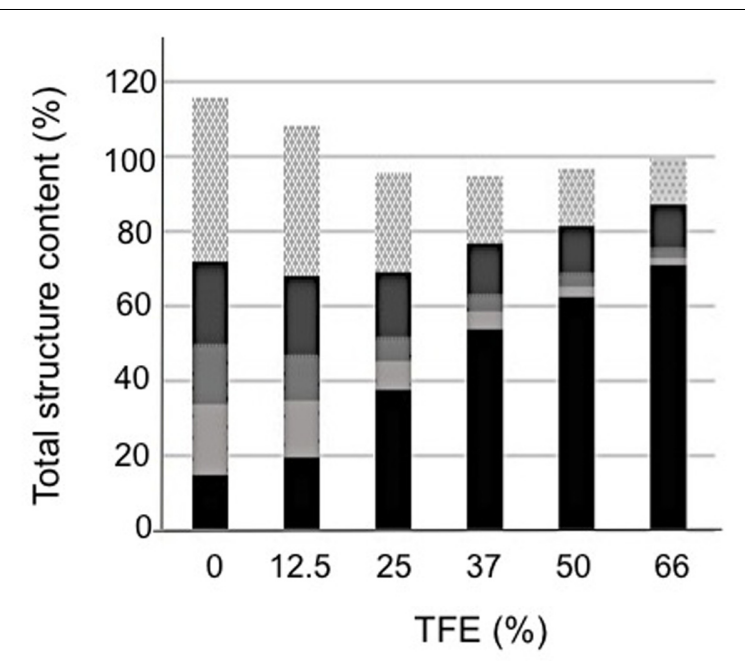

$\alpha$-helix
$\beta$-sheet antipar $\quad \square$-sheet par
$\beta$-turn

FIGURE 5 | Structural composition vs. TFE concentration in rAcLEA solution as calculated from respective $C D$ data using CDNN software.

being further decreased in the presence of TFE (Figure 4F), thus confirming the absence of TFE-induced tertiary structure formation.

\section{Biological Properties of AcLEA In vivo Using E. coli as a Model}

It has been demonstrated that the expression system of $E$. coli is a simple, convenient, and effective model to determine the function of recombinant proteins (Liu and Zheng, 2005). So we used the transformed E. coli DE3 cells to evaluate their tolerance to diverse types of abiotic stress conditions (desiccation, $\mathrm{NaCl}$, $\mathrm{H}_{2} \mathrm{O}_{2}$, sorbitol, and PEG-4000).

Figure 6A shows the growth kinetics of control E. coli cells transformed with empty plasmid (control) and pET28modAcLEA plasmid. It has been reported that expression of LEA (group 1) genes from plants has no effect on the growth kinetics of transformed E. coli or yeast cells (Lan et al., 2005; Campos et al., 2006; Dang et al., 2014). These results are in agreement with our results; however, Warner et al. (2016) reported that induction of AfrLEA-1 (Artemia franciscana LEA group 1) was associated with inhibition of Top $10 \mathrm{~F}^{\prime}$ E. coli on account of basic $\mathrm{p} I$ of AfrLEA-1. Curiously AcLEA has also a basic $\mathrm{p} I$ but we did not observe such cell growth inhibition.

It has been suggested that hydrophilic and heat-stable proteins may modify the structure of other proteins and bind water directly to attenuate the damage caused by desiccation (Houde et al., 1992). Figure 6B shows a clear difference in the number of $E$. coli viable cells before and after desiccation stress. Before drying process very similar CFU (expressed in $\times 10^{6}$ units) were obtained for control and AcLEA expressing cells, but after desiccation, although only a very small fraction of cells survived, the number of CFU expressing AcLEA were three times higher than in control cells. This result suggests that AcLEA expression E. coli improved its survival capacity after desiccation. On the other hand, it is well known that the E. coli growth rate is strongly influenced by the salt content present in the growth medium (Gowrishankar, 1985). Lan et al. (2005) and Reddy et al. (2012) showed that overexpression of LEA group 1 from plants in E. coli provides an increased tolerance to the harmful effects of high salinity environments. Liu and Zheng (2005) indicated that the expression of PM2, a LEA group 3 from soybean, enhances salt tolerance of E. coli cells and that the 22-mer repeat region is an important functional region in this protein. As shown in Figure $6 \mathrm{C}$, the E. coli growth was inhibited by addition of $\mathrm{NaCl}$ and contrarily to other reports, the expression of AcLEA did not change this behavior. Because AcLEA has been classified as LEA Group 3 it was expected that it would participated in the protection of cells against salt stress, however, the differences in the amino acid sequences detected in AcLEA (Figure 1A) could be responsible for this observed difference.

Low ROS concentrations can act as messengers to regulate biological process, while high ROS concentrations can have very harmful effects and dehydration will disrupt the metabolism of seeds leading to high ROS production (Bailly et al., 2008). In Figure 6D is shown that even at high $\mathrm{H}_{2} \mathrm{O}_{2}$ concentration, AcLEA conferred a significant tolerance to $E$. coli cells. On the other hand, Warner et al. (2016) reported that in general E. coli strains tolerate low sorbitol concentrations. Our results showed that AcLEA was able to overcome the negative sorbitol effect on $E$. coli growth even at $1 \mathrm{M}$ concentration (Figure 6E). E. coli growth was also tested in the presence of PEG as a compound that decreases the osmotic potential of the cells. As shown in Figure 6F, the accumulation of AcLEA improved the growth cell supporting an osmoprotection function.

\section{In situ Localization of AcLEA}

To decipher the subcellular localization of AcLEA protein, the corresponding coding sequence was fused with green fluorescent protein (AcLEA-GFP) in vectors designed for transient transgene expression in $N$. benthamiana leaf protoplasts. Confocal microscopy images (Figure 7A) of protoplasts from leaves infiltrated with the expression vector pEarlyGate103-AcLEA clearly show that AcLEA protein exhibits a cytosolic localization in these conditions. The accumulation of AcLEA and GFP proteins in infiltrated leaves was confirmed by immunodetection analysis (Figure 7B). It is noted that cytosolic LEA proteins could be involved in stress protection not only within the cytosol itself but also at the level of membranes delimiting the organelles such as mitochondria, chloroplasts, endoplasmic reticulum, and nucleus (Candat et al., 2014).

\section{AcLEA Localization in Amaranth Seeds and Plant Tissues}

Anti-AcLEA antibodies were sensitive to detect the corresponding polypeptides in extracts from seed proteins from different amaranth wild and domesticated species. Among 
A

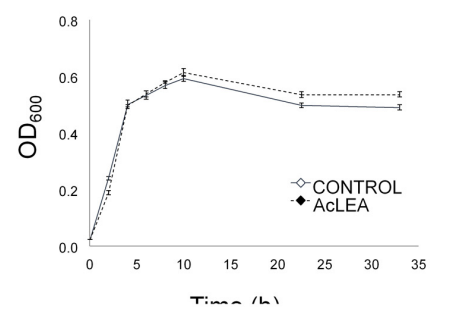

D

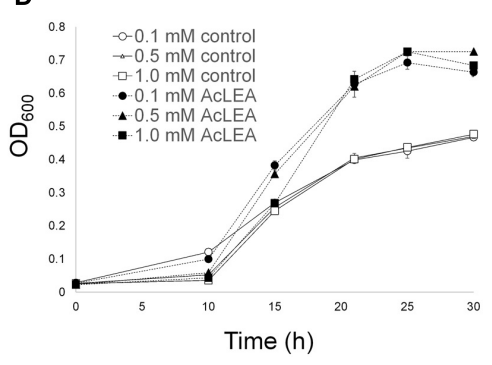

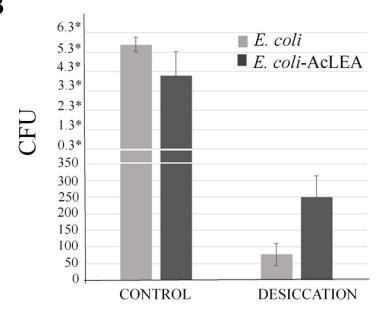

E

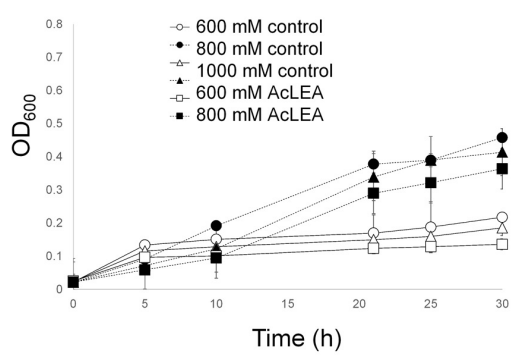

C

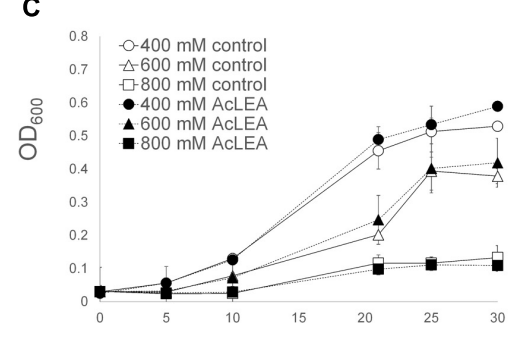

$\mathbf{F}$

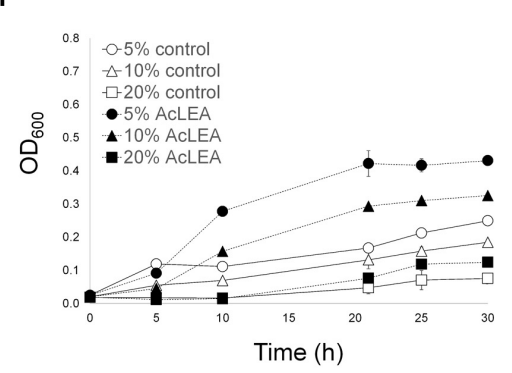

FIGURE 6 | Escherichia coli growth in different stress conditons. Cells were grown overnight in LB medium (with antibiotic) and their concentration was determined. An equal number of cells were added to flask with LB (control) and LB containing: $\mathrm{NaCl}, \mathrm{H}_{2} \mathrm{O}_{2}$, sorbitol or PEG as indicated. (A) Growth kinetics of E. coli transformed with pET28mod (control) and pET28mod-AcLEA. Cells were grown until optical density at $600 \mathrm{~nm}$ reached 0.6 then $0.1 \mathrm{mM} \mathrm{IPTG}$ was and incubated for $2 \mathrm{~h}$ at $28^{\circ} \mathrm{C}$. (B) Cell viability related to colony former units (CFU) before (control) and after desiccation. ${ }^{*} \times 10^{6}$ cells. (C) Effect of salinity stress induced by $\mathrm{NaCl}$. (D) Oxidant stress caused by additon of $\mathrm{H}_{2} \mathrm{O}_{2}$. (E,F) Effect of dehydration stress and osmotic potential stress simulated by the additon of sorbitol and PEG-4000, respectively. Each curve/column represents an average of three biological experiments with three replicates each. Bars in each figure represent the standard deviation.

A

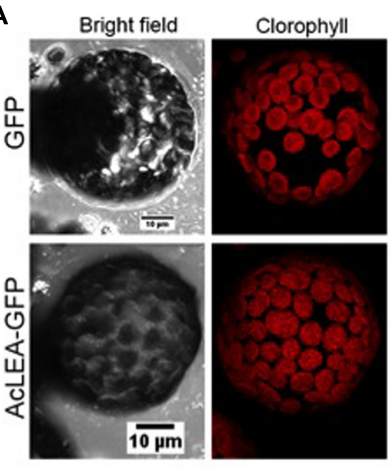

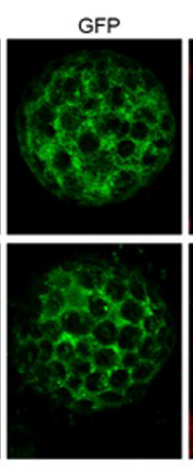

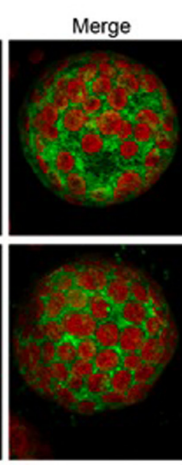

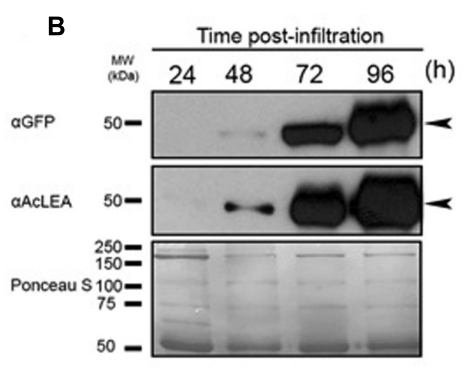

FIGURE 7 | AcLEA subcellular localization using the Nicotiana benthamiana system. (A) Confocal microscopy images of protoplasts from N. benthamiana leaves infiltrated with the expression vector pEarlyGate103 (GFP) and pEarlyGate10-AcLEA-GFP. Images were captured $96 \mathrm{~h}$ after infiltration of indicated constructs in bright field and in fluorescence using an excitation laser of 488 and emission filters BA655-755 for chlorophyll and BA505-605 for GFP. A merged image is also shown. (B) Immunoblots of kinetics of expression and accumulation of proteins infiltrated at the indicated times. Below immunodetection autoradiographs, the Ponceau S stained membrane is shown as loading control.

all species analyzed, no differences in abundance were observed in seeds (Figures 8A,B and Supplementary Figure S7). This could indicate that AcLEA plays an important function most likely during seed drying process. To identify all sequences related with LEA proteins, we carried out a search in phytozome database ${ }^{7}$. Sixty matches were retrieved but only one of those sequences (AHYPO_005092) was identical to AcLEA (Supplementary

${ }^{7}$ https://phytozome.jgi.doe.gov/pz/portal.html
Figure S8), which correlates with the Western blot analysis where only one reactive band was observed (Figure 8B).

The abundance of AcLEA was tested also on leaves, stems, and roots of wild and domesticated amaranth species. Under normal conditions of plant growth of watering, AcLEA was not detected (Figures 8C,D). But very interestingly, when plants were subjected to salinity stress, we observed the accumulation of AcLEA (Figures 8E,F). As shown in Figure 8F, AcLEA accumulation was observed in A. hypochondriacus leaves in the 


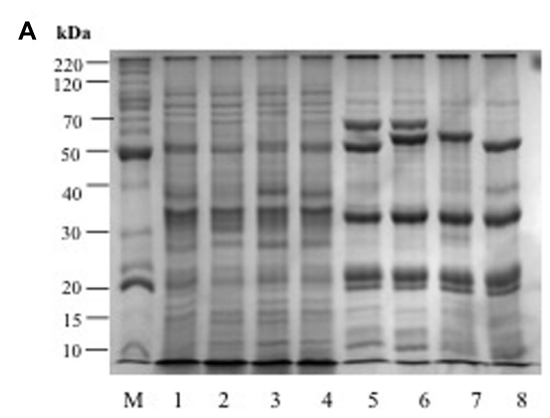

C

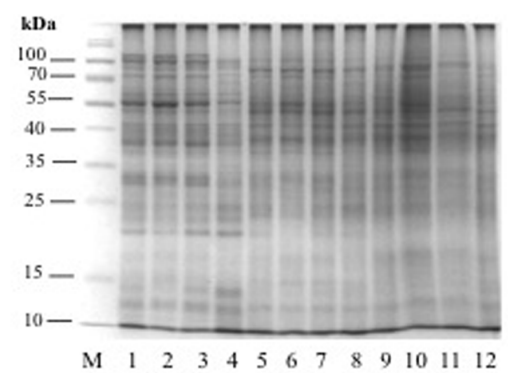

E

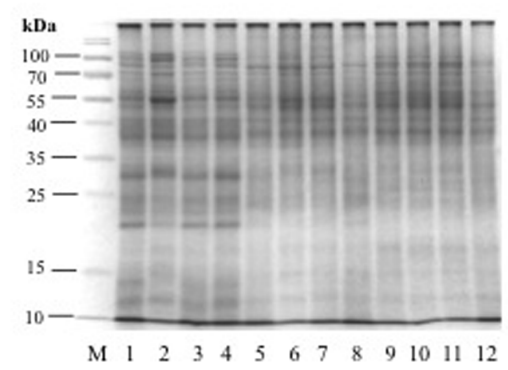

B kDa

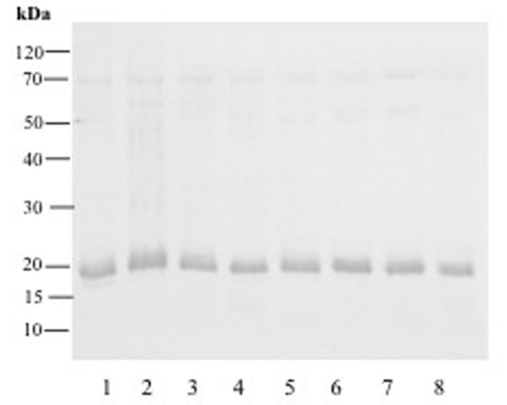

D

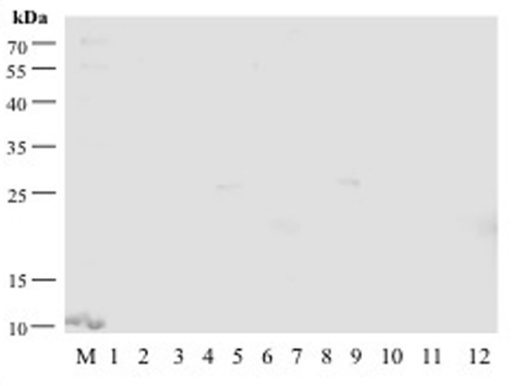

F

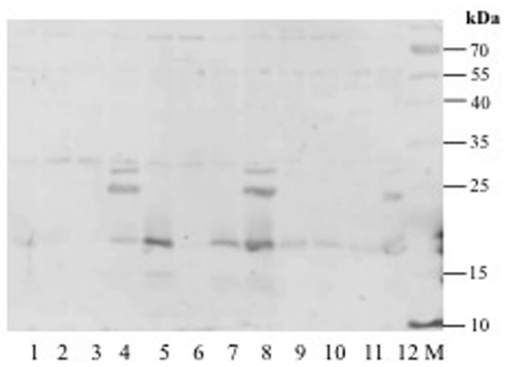

FIGURE 8 | (A) SDS-PAGE profile from amaranth seed storage proteins: Lane $\mathrm{M}=$ molecular weigh marker, Lanes 1-4 = hydrophilic proteins from: $A$. hybridus, A. powellii, A. cruentus, and A. hypochondriacus, respectively. Lanes 5-8= hydrophobic proteins from: A. hybridus, A. powellii, A. cruentus, and A. hypochondriacus, respectively. (B) Western Blot analysis against anti-AcLEA. (C) SDS-PAGE profile from amaranth leaves, stems, and roots from plants growing under normal conditions: Lane $\mathrm{M}=$ molecular weight marker; Lanes 1-4 = leaf proteins from: $A$. hybridus, A. powellii, A. cruentus, and A. hypochondriacus, respectively; Lanes 5-8 = stem proteins from: $A$. hybridus, $A$. powellii, $A$. cruentus, and $A$. hypochondriacus, respectively; Lanes $9-12=$ root proteins from: $A$. hybridus, A. powellii, A. cruentus, and A. hypochondriacus, respectively. (D) Western blot analysis against AcLEA. (E) SDS-PAGE profile from amaranth leaves, stems, and roots from plants subjected to salinity stress: Lane $\mathrm{M}=$ molecular weight marker; Lanes $1-4=$ leaf proteins from of $A$. hybridus, $A$. powellii, $A$. cruentus, and $A$. hypochondriacus, respectively; Lanes $5-8=$ stem proteins from of $A$. hybridus, $A$. powellii, $A$. cruentus, and $A$. hypochondriacus, respectively; Lanes 9-12 = root proteins from of $A$. hybridus, A. powellii, A. cruentus, and A. hypochondriacus, respectively. (F) Western blot analysis against AcLEA.

expected size (19 kDa, Supplementary Figure S7) but also two more bands around 25 and $30 \mathrm{kDa}$ were observed. In leaves of wild species, the $19 \mathrm{kDa}$ band was barely observed, but in stems a strong band was observed in the wild species $A$. hybridus and the domesticated A. cruentus and A. hypochondriacus. Meanwhile in roots the $19 \mathrm{kDa}$ band was detected in all species, but at much lower accumulation. These results have shown that AcLEA is conserved in seeds among amaranth species, but that AcLEA plays an important function in response to plant stress and its tissue-specific accumulation was observed.

\section{CONCLUSION}

We present the isolation, cloning, structural and functional characterization of the first LEA from Amaranthus species
(AcLEA). The deduced amino acid sequence of this gene showed that AcLEA belongs to the LEA proteins group 3 and structural analysis in solution has shown that it belongs to IDPs lacking of a well-defined secondary or tertiary structure, but has a strong tendency to adopt a helical conformation. Using E. coli as in vivo model to evaluate the AcLEA function it was shown that this protein displayed a protective effect against desiccation, osmotic, and oxidative stresses. In N. benthamiana leaf protoplasts AcLEA was observed as being localized to the cytosol. Moreover, AcLEA was detected in different tissues from wild and domesticated amaranth species suggesting the important function of AcLEA protein as osmoprotectant during seed desiccation. But interestingly, AcLEA was accumulated in leaves and stems in response to salt stress. These results highlighted the importance of AcLEA as an important protein for stress protection in amaranth species. 


\section{AUTHOR CONTRIBUTIONS}

AS and APBR conceived and designed the work. AS and EEHD cloned the AcLEA gene in E. coli system. LdL-V and AG-G, carried out $N$. benthamiana transient transformation. AS and DF-V carried out CD analysis and AS and FdR-P carried out the NMR analysis. AS and AE-M prepared the anti-AcLEA antibodies in rabbits, EB-V conducted Western blot analysis. AS and APBR drafted the manuscript and all authors reviewed and approval the final manuscript.

\section{ACKNOWLEDGMENTS}

AS and EH give thanks to CONACYT-Mexico postdoctoral fellow 232286 and 290754, respectively. LdL-V thanks CONACYT-Mexico by the doctoral fellowship 240088. We

\section{REFERENCES}

Acton, T. B., Gunsalus, K. C., Xiao, R., Ma, L. C., Aramini, J., Baran, M. C., et al. (2005). Robotic cloning and protein production platform of the northeast structural genomics consortium. Methods Enzymol. 394, 210-243. doi: 10.1016/ S0076-6879(05)94008-1

Agoston, B. S., Kovacs, D., Tompa, P., and Perczel, A. (2011). Full backbone assignment and dynamics of the intrinsically disordered dehydrin ERD14. Biomol. NMR Assign. 5, 189-193. doi: 10.1007/s12104-011-9297-2

Aguilar-Hernández, H. S., Santos, L., Leon-Galvan, F., Barrera-Pacheco, A. Espitia-Rangel, E., De Leon-Rodriguez, A., et al. (2011). Identification of calcium stress induced genes in amaranth leaves through suppression subtractive hybridization. J. Plant Physiol. 168, 2102-2109. doi: 10.1016/j.jplph. 2011.06.006

Ali-Benali, M. A., Alary, R., Joudrier, P., and Gautier, M. F. (2005). Comparative expression of five Lea Genes during wheat seed development and in response to abiotic stresses by real-time quantitative RT-PCR. Biochim. Biophys. Acta 1730, 56-65. doi: 10.1016/j.bbaexp.2005.05.011

Avelange-Macherel, M. H., Payet, N., Lalanne, D., Neveu, M., Tolleter, D., Burstin, J., et al. (2015). Variability within a pea core collection of LEAM and HSP22, two mitochondrial seed proteins involved in stress tolerance. Plant Cell Environ. 38, 1299-1311. doi: 10.1111/pce.12480

Bailly, C., El-Maarouf-Bouteau, H., and Corbineau, F. (2008). From intracellular signaling networks to cell death: the dual role of reactive oxygen species in seed physiology. C R Biol. 331, 806-814. doi: 10.1016/j.crvi.2008.07.022

Battaglia, M., and Covarrubias, A. A. (2013). Late embryogenesis abundant (LEA) proteins in legumes. Front. Plant Sci. 4:190. doi: 10.3389/fpls.2013.00190

Battaglia, M., Olvera-Carrillo, Y., Garciarrubio, A., Campos, F., and Covarrubias, A. A. (2008). The enigmatic LEA proteins and other hydrophilins. Plant Physiol. 148, 6-24. doi: 10.1104/pp.108.120725

Becker, R., Wheeler, E. L., Lorenz, K. A., Staffor, E., Grosjean, O. K., Betschart, A. A., et al. (1981). A compositional study of amaranth grain. J. Food Sci. 46, 1175-1180. doi: 10.1111/j.1365-2621.1981.tb03018.x

Bohm, G., Muhr, R., and Jaenicke, R. (1992). Quantitative analysis of protien far UV ciruclar dichroism spectra by neural networks. Protein Eng. 5, 191-195. doi: $10.1093 /$ protein/5.3.191

Boswell, L. C., Menze, M. A., and Hand, S. C. (2014). Group 3 late embryogenesis abundant proteins from embryos of Artemia franciscana: structural properties and protective abilities during desiccation. Physiol. Biochem. Zool. 87, 640-651. doi: $10.1086 / 676936$

Boucher, V., Buitink, J., Lin, X., Boudet, J., Hoekstra, F. A., Hundertmark, M., et al. (2010). MtM25 is an atypical hydrophobic late embryogenesis-abundant protein that dissociates cold and desiccation-aggregated proteins. Plant Cell Environ. 33, 418-430. doi: 10.1111/j.1365-3040.2009.02093.x

Brenner, D. M., Baltensperger, D. D., Kulakow, P. A., Lehmann, J. W., Myers, R. L., Slabbert, M. M., et al. (2000). "Genetic resources and breeding of amaranthus," also thank to CONACYT-Mexico Grants 56787 (Laboratory for Nanoscience and Nanotechnology Research-LINAN) and 204373 (Infrastructure project, INFRA-2013-01), and 251848 (CB-2015). We thank to Alberto Barrera-Pacheco for his technical assistance in MS/MS analysis. LdL-V and AG-G thank to LNMA for confocal microscopy images. We thank to Fabiola Veana Hernández for her technical assistance. We thank to Project "Problemas Nacionales-Amaranto en la soberanía alimentaria" No. 248415.

\section{SUPPLEMENTARY MATERIAL}

The Supplementary Material for this article can be found online at: http://journal.frontiersin.org/article/10.3389/fpls.2017.00497/ full\#supplementary-material

in Plant Breeding Reviews, Vol. 19, ed. J. Janick (Oxford: John Wiley \& Sons, Inc).

Browne, J., Tunnacliffe, A., and Burnell, A. (2002). Anhydrobiosis: plant desiccation gene found in a nematode. Nature 416:38. doi: 10.1038/416038a

Buck, M. (1998). Trifluoroethanol and colleagues: cosolvents come of age. Recent studies with peptides and proteins. Q. Rev. Biophys. 31, 297-355. doi: 10.1017/ S003358359800345X

Campos, F., Cuevas-Velazquez, C., Fares, M. A., Reyes, J. L., and Covarrubias, A. A. (2013). Group 1 LEA proteins, an ancestral plant protein group, are also present in other eukaryotes, and in the archeae and bacteria domains. Mol. Genet. Genomics 288, 503-517. doi: 10.1007/s00438-013-0768-2

Campos, F., Zamudio, F., and Covarrubias, A. A. (2006). Two different late embryogenesis abundant proteins from Arabidopsis thaliana contain specific domains that inhibit Escherichia coli growth. Biochem. Biophys. Res. Commun. 342, 406-413. doi: 10.1016/j.bbrc.2006.01.151

Candat, A., Paszkiewicz, G., Neveu, M., Gautier, R., Logan, D. C., AvelangeMacherel, M.-H., et al. (2014). The ubiquitous distribution of late embryogenesis abundant proteins across cell compartments in Arabidopsis offers tailored protection against abiotic stress. Plant Cell 26, 3148-3166. doi: $10.1105 /$ tpc. 114.127316

Cao, J., and Li, X. (2015). Identification and phylogenetic analysis of late embryogenesis abundant proteins family in tomato (Solanum lycopersicum). Planta 241, 757-772. doi: 10.1007/s00425-014-2215-y

Chakrabortee, S., Meersman, F., Schierle, G. S. K., Bertoncini, C. W., McGee, B., Kaminski, C. F., et al. (2010). Catalytic and chaperone-like functions in an intrinsically disordered protein associated with desiccation tolerance. Proc. Natl. Acad. Sci. U.S.A. 107, 16084-16089. doi: 10.1073/pnas.10062 76107

Clouse, J. W., Adhikary, D., Page, J. T., Ramaraj, T., Deholos, M. K., Udall, J. A., et al. (2016). The amaranth genome: genome, transcriptome, and physical map assembly. Plant Genome 9, 1-14. doi: 10.3835/plantgenome2015.07.0062

Creighton, T. (1993). Proteins. Structure and Molecular Properties, Second Edn. New York, NY: W. H. Freeman.

Dalal, M., Tayal, D., Chinnusamy, V., and Bansal, K. C. (2009). Abiotic stress and ABA-inducible Group 4 LEA from Brassica napus plays a key role in salt and drought tolerance. J. Biotechnol. 139, 137-145. doi: 10.1016/j.jbiotec.2008. 09.014

Dang, N. X., Popova, A. V., Hundertmark, M., and Hincha, D. K. (2014). Functional characterization of selected LEA proteins from Arabidopsis thaliana in yeast and in vitro. Planta 240, 325-336. doi: 10.1007/s00425-014-2089-z

Delano-Frier, J. P., Aviles-Arnaut, H., Casarrubias-Castillo, K., Casique-Arroyo, G., Castrillon-Arbelaez, P. A., Herrera-Estrella, L., et al. (2011). Transcriptomic analysis of grain amaranth (Amaranthus hypochondriacus) using 454 pyrosequencing: comparison with A. tuberculatus, expression profiling in stems and in response to biotic and abiotic stress. BMC Genomics 12:363. doi: 10.1186/ 1471-2164-12-363 
Denekamp, N. Y., Reinhardt, R., Kube, M., and Lubzens, E. (2010). Late embryogenesis abundant (LEA) proteins in nondesiccated, encysted, and diapausing embryos of rotifers. Biol. Reprod. 82, 714-724. doi: 10.1095/ biolreprod.109.081091

Dure, L. III (1989). Common amino acid sequence domains among the LEA proteins of higher plants. Plant Mol. Biol. 12, 475-486. doi: 10.1007/ BF00036962

Dure, L. (1993). A repeating 11-mer amino acid motif and plant desiccation. Plant J. 3, 363-369. doi: 10.1046/j.1365-313X.1993.t01-19-00999.x

Edgar, R. C. (2004). MUSCLE: multiple sequence alignment with high accuracy and high throughput. Nucleic Acids Res. 32, 1792-1797. doi: 10.1093/nar/ gkh340

Finn, R. D., Coggill, P., Eberhardt, R. Y., Eddy, S. R., Mistry, J., Mitchell, A. L., et al. (2015). The Pfam protein families database: towards a more sustainable future. Nucleic Acids Res. 44, D279-D285. doi: 10.1093/nar/gkv1344

Furuki, T., Shimizu, T., Kikawada, T., Okuda, T., and Sakurai, M. (2011). Salt effects on the structural and thermodynamic properties of a group 3 LEA protein model peptide. Biochemistry 50, 7093-7103. doi: 10.1021/bi200719s

Gai, Y. P., Ji, X. L., Lu, W., Han, X. J., Yang, G. D., and Zheng, C. C. (2011). A novel late embryogenesis abundant like protein associated with chilling stress in Nicotiana tabacum cv. bright yellow-2 cell suspension culture. Mol. Cell. Proteom. 10, M111.010363. doi: 10.1074/mcp.M111.010363

Garay-Arroyo, A., Colmenero-Flores, J. M., Garciarrubio, A., and Covarrubias, A. A. (2000). Highly hydrophilic proteins in prokaryotes and eukaryotes are common during conditions of water deficit. J. Biol. Chem. 275, 5668-5674. doi: $10.1074 /$ jbc. 275.8 .5668

Gasteiger, E., Hoogland, C., Gattiker, A., Duvaud, S., Wilkins, M. R., Appel, R. D., et al. (2005). "Protein identification and analysis tools on the ExPASy server," in The Proteomics Protocols Handbook, eds J. M. Walker and N. J. Totowa (New York City, NY: Humana Press Inc), 571-607. doi: 10.1385/1-59259-890$0: 571$

Gowrishankar, J. (1985). Identification of osmoresponsive genes in Escherichia coli: evidence for participation of potassium and proline transport systems in osmoregulation. J. Bacteriol. 164, 434-445.

Goyal, K., Tisi, L., Basran, A., Browne, J., Burnell, A., Zurdo, J., et al. (2003). Transition from natively unfolded to folded state induced by desiccation in an anhydrobiotic nematode protein. J. Biol. Chem. 278, 12977-12984. doi: 10.1074/ jbc.M212007200

Hand, S. C., Menze, M. A., Toner, M., Boswell, L., and Moore, D. (2011). LEA proteins during water stress: not just for plants anymore. Annu. Rev. Physiol. 73, 115-134. doi: 10.1146/annurev-physiol-012110-142203

Hatanaka, R., Furuki, T., Zhimizu, T., Takezawa, D., Kikawada, T., Sakurai, M., et al. (2014). Biochemical and structural characterization of an endoplasmic reticulum-localized late embryogenesis abundant (LEA) protein from the liverwort Marchantia polymorpha. Biochem. Biophys. Res. Commun. 454, 588-593. doi: 10.1016/j.bbrc.2014.10.130

He, S., Tan, L., Hu, Z., Chen, G., Wang, G., and Hu, T. (2012). Molecular characterization and functional analysis by heterologous expression in E. coli under diverse abiotic stresses for OsLEA5, the atypical hydrophobic LEA protein from Oryza sativa L. Mol. Genet. Genomics 287, 39-54. doi: 10.1007/ s00438-011-0660-x

Hincha, D. K., and Thalhammer, A. (2012). LEA proteins: IDPs with versatile functions in cellular dehydration tolerance. Biochem. Soc. Trans. 40, 1000-1003. doi: 10.1042/BST20120109

Houde, M., Danyluk, J., Laliberte, J. F., Rassart, E., Dhindsa, R. S., and Sarhan, F. (1992). Cloning, characterization, and expression of a cDNA encoding a 50kilodalton protein specifically induced by cold acclimation in wheat. Plant Physiol. 99, 1381-1387. doi: 10.1104/pp.99.4.1381

Hu, T., Zhou, N., Fu, M., Qin, J., and Huang, X. (2016). Characterization of OsLEAla and its inhibitory effect on the resistance of $E$. coli to diverse abiotic stresses. Int. J. Biol. Macromol. 91, 1010-1017. doi: 10.1016/j.ijbiomac.2016.06. 056

Huerta-Ocampo, J. A., Barrera-Pacheco, A., Mendoza-Hernández, C. S., EspitiaRangel, E., Mock, H. P., and Barba de la Rosa, A. P. (2014). Salt stress-induced alterations in the root proteome of Amaranthus cruentus L. J. Proteome Res. 13, 3607-3627. doi: 10.1021/pr500153m

Huerta-Ocampo, J. A., Leon-Galvan, M. F., Ortega-Cruz, L. B., BarreraPacheco, A., De Leon-Rodriguez, A., Mendoza-Hernandez, G., et al. (2011).
Water stress induces up-regulation of DOF1 and MIF1 transcription factors and down-regulation of proteins involved in secondary metabolism in amaranth roots (Amaranthus hypochondriacus L.). Plant Biol. 13, 472-482. doi: 10.1111/j. 1438-8677.2010.00391.x

Hunault, G., and Jaspard, E. (2010). LEAPdb: a database for the late embryogenesis abundant proteins. BMC Genomics 11:221. doi: 10.1186/1471-2164-11-221

Hundertmark, M., and Hincha, D. K. (2008). LEA (late embryogenesis abundant) proteins and their encoding genes in Arabidopsis thaliana. BMC Genomics 9:118. doi: 10.1186/1471-2164-9-118

Imai, R., Chang, L., Ohta, A., Bray, E. A., and Takagi, M. (1996). A lea-class gene of tomato confers salt and freezing tolerance when expressed in Saccharomyces cerevisiae. Gene 170, 243-248. doi: 10.1016/0378-1119(95)00868-3

Ingram, J., and Bartels, D. (1996). The molecular basis of dehydration tolerance in plants. Annu. Rev. Plant Physiol. Plant Mol. Biol. 47, 377-403. doi: 10.1146/ annurev.arplant.47.1.377

Jaspard, E., Macherel, D., and Hunault, G. (2012). Computational and statistical analyses of amino acid usage and physic-chemical properties of the twelve late embryogenesis abundant protein classes. PLoS ONE 7:e36868. doi: 10.1371/ journal.pone.0036968

Karimi, M., Depicker, A., and Hilson, P. (2007). Recombinational cloning with plant gateway vectors. Plant Physiol. 145, 1144-1154. doi: 10.1104/pp.107. 106989

Kyte, J., and Doolittle, R. F. (1982). A simple method for displaying the hydropathic character of a protein. J. Mol. Biol. 157, 105-132. doi: 10.1016/0022-2836(82) 90515-0

Lan, Y., Cai, D., and Zheng, Y.-Z. (2005). Expression in Escherichia coli of three different soybean late embryogenesis abundant (LEA) genes to investigate enhanced stress tolerance. J. Integr. Plant Biol. 47, 613-621. doi: 10.1111/j.17447909.2005.00025.x

Liu, Y., Wang, L., Xing, X., Sun, L., Pan, J., Kong, X., et al. (2013). ZmLEA3, a multifunctional Group 3 LEA protein from maize (Zea mays L.), is involved in biotic and abiotic stresses. Plant Cell Physiol. 54, 944-959. doi: 10.1093/pcp/ pct047

Liu, Y.-L., and Zheng, Y.-Z. (2005). PM2, a group 3 LEA protein from soybean, and its 22-mer repeating region confer salt tolerance in Escherichia coli. Biochem. Biophys. Res. Commun. 331, 325-332. doi: 10.1016/j.bbrc.2005.03.165

Maldonado-Cervantes, E., Huerta-Ocampo, J. A., Montero-Moran, G. M., BarreraPacheco, A., Espitia-Rangel, E., and Barba de la Rosa, A. P. (2014). Characterization of Amaranthus cruentus L. seed proteins by 2-DE and LC/MSMS: identification and cloning of a novel late embryogenesis-abundant protein. J. Cereal Sci. 60, 172-178. doi: 10.1016/j.jcs.2014.02.008

Maughan, P. J., Yourstone, S. M., Jellen, E. N., and Udall, J. A. (2009). SNP discovery via genomic reduction, barcoding, and 454-Pyrosequencing in amaranth. Plant Genome 2, 260-270. doi: 10.3835/plantgenome2009.08.0022

Mielke, S. P., and Krishnan, V. V. (2009). Characterization of protein secondary structure from NMR chemical shifts. Prog. Nucl. Magn. Reson. Spectrosc. 54, 141-165. doi: 10.1016/j.pnmrs.2008.06.002

Muller, I., Sarramégna, V., Renault, M., Lafaquière, V., Sebai, S., Milon, A., et al. (2008). The full-length Mu-opioid receptor: a conformational study by circular dichorism in trifluoroethanol and membrane-mimetic environments. J. Membrane Biol. 223, 49-57. doi: 10.1007/s00232-008-9112-x

Olvera-Carrillo, Y., Campos, F., Reyes, J. L., Garciarrubio, A., and Covarrubias, A. A. (2010). Functional analysis of the Group 4 late embryogenesis abundant proteins reveals their relevance in the adaptive response during water deficit in Arabidopsis. Plant Physiol. 154, 373-390. doi: 10.1104/pp.110.158964

Popova, A. V., Hundertmark, M., Seckler, R., and Hincha, D. K. (2011). Structural transitions in the intrinsically disordered plant dehydration stress protein LEA7 upon drying are modulated by the presence of membranes. Biochim. Biophys. Acta 1808, 1879-1887. doi: 10.1016/j.bbamem.2011.03.009

Rastogi, A., and Shukla, S. (2013). Amaranth: a new millennium crop of nutraceutical values. Crit. Rev. Food Sci. Nutr. 53, 109-125. doi: 10.1080/ 10408398.2010.517876

Reddy, P. S., Reddy, G. M., Pandey, P., Chandrasekhar, K., and Reddy, M. K. (2012). Cloning and molecular characterization of a gene encoding late embryogenesis abundant protein from Pennisetum glaucum: protection against abiotic stresses. Mol. Biol. Rep. 39, 7163-7174. doi: 10.1007/s11033-012-1548-5

Rivera-Najera, L. Y., Saab-Rincon, G., Battaglia, M., Amero, C., Pulido, N. O., Garcia-Hernandez, E., et al. (2014). A group 6 late embryogenesis abundant 
protein from common bean Is a disordered protein with extended helical structure and oligomer-forming properties. J. Biol. Chem. 289, 31995-32009. doi: $10.1074 /$ jbc.M114.583369

Saitou, N., and Nei, M. (1987). The neighbor-joining method: a new method for reconstruction phylogenetic trees. Mol. Biol. Evol. 4, 406-425.

Sasaki, K., Christov, N. K., Tsuda, S., and Imai, R. (2014). Identification of a novel LEA protein involved in freezing tolerance in wheat. Plant Cell Physiol. 55, 136-147. doi: 10.1093/pcp/pct164

Serrano, L., Sancho, J., Hirshberg, M., and Fersht, A. R. (1992). Alpha-helix stability in proteins. I. Empirical correlations concerning substitution of side-chains at the $\mathrm{N}$ and $\mathrm{C}$-caps and the replacement of alanine by glycine or serine at solvent-exposed surfaces. J. Mol. Biol. 227, 544-559. doi: 10.1016/0022-2836(92) 90906-Z

Shih, M. D., Lin, S. D., Hsieh, J. S., Tsou, C. H., Chow, T. Y., Lin, T. P., et al. (2004). Gene cloning and characterization of a soybean (Glycine max L.) LEA protein, GmPM16. Plant Mol. Biol. 56, 689-703. doi: 10.1007/s11103-004-4680-3

Silva-Sánchez, C., Barba de la Rosa, A. P., León-Galván, M. F., de Lumen, B. O., De León-Rodríguez, A., and González de Mejía, E. (2008). Bioactive peptides in amaranth (Amaranthus hypochondriacus) seed. J. Agric. Food Chem. 56, 1233-1240. doi: 10.1021/jf072911z

Singh, S., Cornilescu, C. C., Tyler, R. C., Cornilescu, G., Tonelli, M., Lee, M. S., et al. (2005). Solution structure of a late embryogenesis abundant protein (LEA14) from Arabidopsis thaliana, a cellular stress-related protein. Protein Sci. 2005, 2601-2609. doi: 10.1110/ps.051579205

Sivamani, E., Bahieldin, A., Wraith, J. M., Al-Niemi, T., Dyer, W. E., Ho, T., et al. (2000). Improved biomass productivity and water use efficiency under water deficit conditions in transgenic wheat constitutively expressing the barley HVA1 gene. Plant Sci. 155, 1-9. doi: 10.1016/S0168-9452(99)00247-2

Soulages, J. L., Kim, K., Walters, C., and Cushman, J. C. (2002). Temperatureinduced extended helix/random coil transitions in a group 1 late embryogenesis-abundant protein from soybean. Plant. Physiol. 128, 822-832. doi: $10.1104 /$ pp.010521

Tolleter, D., Hincha, D. K., and Macherel, D. (2010). A mitochondrial late embryogenesis abundant protein stabilizes model membranes in the dry state. Biochim. Biophys. Acta 1798, 1926-1933. doi: 10.1016/j.bbamem.2010.06.029

Tolleter, D., Jaquinod, M., Mangavel, C., Passirani, C., Saulnier, P., Manon, S., et al. (2007). Structure and function of a mitochondrial late embryogenesis abundant protein are revealed by desiccation. Plant Cell 19, 1580-1589. doi: $10.1105 /$ tpc.107.050104

Tompa, P., and Kovacs, D. (2010). Intrinsically disordered chaperones in plants and animals. Biochem. Cell Biol. 88, 167-174. doi: 10.1139/o09-163

Tunnacliffe, A., Hincha, D. K., Leprince, O., and Macherel, D. (2010). "LEA proteins: versa-tility of form and function," in Sleeping Beauties: Dormancy and Resistance in Harsh Environments, eds E. Lubzens, J. Cerda, and M. Clark (Berlin: Springer), 91-108. doi: 10.1007/978-3-642-12422-8_6

Tunnacliffe, A., and Wise, M. J. (2007). The continuing conundrum of the LEA proteins. Naturwissenschaften 94, 791-812. doi: 10.1007/s00114-007-0254-y
Valdes-Rodríguez, S., Guerrero-Rangel, A., Melgoza-Villagomez, C., ChagollaLopez, A., Delgado-Vargas, F., Martinez-Gallardo, N., et al. (2007). Cloning of a cDNA encoding a cystatin from grain amaranth (Amaranthus hypochondriacus) showing a tissue-specific expression that is modified by germination and abiotic stress. Plant Physiol. Biochem. 45, 790-798. doi: 10.1016/j.plaphy.2007. 07.007

van Leeuwen, M. R., Wyatt, T. T., van Doorn, T. M., Lugones, L. G., Wösten, H. A. B., and Dijksterhuis, J. (2016). Hydrophilins in the filamentous fungus Neosartorya fischeri (Aspergillus fischeri) have protective activity against several types of microbial water stress. Environ. Microbiol. Rep. 8, 45-52. doi: 10.1111/ 1758-2229.12349

Voinnet, O., Rivas, S., Mestre, P., and Baulcombe, D. (2003). An enhanced transient expression system in plants based on suppression of gene silencing by the p19 protein of tomato bushy stunt virus. Plant J. 33, 949-956. doi: 10.1046/j.1365-313X.2003.01676.x

Warner, A. H., Guo, Z.-H., Moshi, S., Hudson, J. W., and Kozarova, A. (2016). Study of model systems to test the potential function of Artemia group 1 late embryogenesis abundant (LEA) proteins. Cell Stress Chaperones 21, 139-154. doi: 10.1007/s12192-015-0647-3

Wishart, D. S., Sykes, B. D., and Richards, F. M. (1991). Simple techniques for the quantification of protein secondary structure by H-1 NMR spectroscopy. FEBS Lett. 293, 1-2. doi: 10.1016/0014-5793(91)81155-2

Wolkers, W. F., McCready, S., Brandt, W. F., Lindsey, G. G., and Hoekstra, F. A. (2001). Isolation and characterization of a D-7 LEA protein from pollen that stabilizes glasses in vitro. Biochim. Biophys. Acta 1544, 196-206. doi: 10.1016/ S0167-4838(00)00220-X

Wu, Y., Liu, C., Kuang, J., Ge, Q., Zhang, Y., and Wang, Z. (2014). Overexpression of SmLEA enhances salt and drought tolerance in Escherichia coli and Salvia miltiorrhiza. Protoplasma 251, 1191-1199. doi: 10.1007/s00709-014-0 626-z

Xu, D., Duan, X., Wang, B., Hong, B., Ho, T., and Wu, R. (1996). Expression of a late embryogenesis abundant protein gene, HVA1, from barley confers tolerance to water deficit and salt stress in transgenic rice. Plant Physiol. 110, 249-257. doi: 10.1104/pp.110.1.249

Conflict of Interest Statement: The authors declare that the research was conducted in the absence of any commercial or financial relationships that could be construed as a potential conflict of interest.

Copyright (c) 2017 Saucedo, Hernández-Domínguez, de Luna-Valdez, GuevaraGarcía, Escobedo-Moratilla, Bojorquéz-Velázquez, del Río-Portilla, FernándezVelasco and Barba de la Rosa. This is an open-access article distributed under the terms of the Creative Commons Attribution License (CC BY). The use, distribution or reproduction in other forums is permitted, provided the original author(s) or licensor are credited and that the original publication in this journal is cited, in accordance with accepted academic practice. No use, distribution or reproduction is permitted which does not comply with these terms. 